\title{
REVIEW
}

\section{Effects of climate variability and change on Chinese agriculture: a review}

\author{
Yue $\mathrm{Li}^{1}{ }^{1}$, Declan Conway ${ }^{2, *}$, Wei Xiong ${ }^{1}$, Qingzhu Gao $^{1}$, Yanjuan Wu ${ }^{1}$, Yunfan Wan ${ }^{1}$, \\ Yan $\mathrm{Li}^{3}$, Silong Zhang ${ }^{3}$ \\ ${ }^{1}$ Institute of Environment and Sustainable Development in Agriculture, Chinese Academy of Agricultural Sciences, \\ Beijing 100081, PR China \\ ${ }^{2}$ School of International Development/Tyndall Centre for Climate Change Research, University of East Anglia, Norwich, \\ NR4 7TJ, UK \\ ${ }^{3}$ Water Resources Information Center, Ministry of Water Resources, Beijing, China
}

\begin{abstract}
Evidence is reviewed from Chinese and international sources on the impacts of observed climate trends and extremes and of potential future climate change on agriculture. Recent climate behaviour in China shows progressive warming and complex patterns of precipitation variability and frequency of extreme events. Agricultural production data highlight substantial economic impacts from extreme climate events, with droughts causing the greatest effects on production. Observed warming has contributed to northward and northeastward expansion of winter wheat and maize cultivation, respectively. Multi-model climate change projections consistently predict warming throughout China and, with reasonable consistency, increases in precipitation across most of the country (averaging $+5 \%$ to $+7 \%$ by 2050 , compared with 1961-1990). Studies of future climate change impacts on crops in China show a wide range of results, primarily due to differences among climate model projections, the methods used to assess crop impacts and whether the effects of $\mathrm{CO}_{2}$ fertilisation are included. Because of China's large size and range of agro-ecological conditions, sensitivity and exposure can vary considerably, leading to complex spatial patterns of response. Crop type and variety, and whether a crop is irrigated or rain-fed also affect yield. The review highlights research priorities, which include the need to systematically monitor, retrieve and analyse observed data on climate-yield behaviour, compare results of different modelling approaches and climate scenarios, and integrate climate effects within a broader framing of food systems.
\end{abstract}

KEY WORDS: Climate variability $\cdot$ Climate change $\cdot$ Climate impacts $\cdot$ Agriculture $\cdot$ Economic impacts $\cdot$ China

\section{INTRODUCTION}

Agricultural production and food security are critical areas where anthropogenic climate change is likely to produce significant impacts. Nowhere is this issue more pressing than in China, where exposure and sensitivity to climatic hazards is high; because of its size and geographical diversity, China experiences many types of climatic hazards, and because of its transitional economy, production and employment in agriculture remain very important, such that hundreds of millions of livelihoods remain vulnerable to climatic hazards. For example, China experienced a serious drought across 5 provinces in southwest China which lasted for 6 mo from the end of 2009 to April 2010. By the end of March 2010, 7.7 million ha 
of farmland had been affected, and over 24 million people and 15 million livestock had difficulty accessing drinking water. Direct economic losses in the 5 provinces exceeded 23.7 billion Yuan RMB (ca. US\$ 3.6 billion; MCA 2010a). In 2010 as well, ongoing flooding across China had led to 1454 deaths and 669 missing people (MCA 2010b). Extremely low temperatures and heavy snowfall during January and February 2008 (the heaviest in 50 yr) in southern China brought massive disruption to transport networks during the peak travel period of the Spring Festival in 2008. The snowfall damaged critical transport nodes and infrastructure for the supply of electricity, coal and other goods. The event caused a direct economic loss of 152 billion Yuan RMB (US\$ 22.5 billion), with $58 \%$ of oil seed rape and $37 \%$ of vegetable production in China affected (CPGC 2008).

These and other such events highlight the challenge that extreme events pose for China. They also provide useful case studies for designing adaptation strategies (e.g. Qiu 2010). Extreme events may act as triggers in policy processes (e.g. flooding in the UK, Penning-Rowsell et al. 2006) by providing a window of opportunity for new policies (e.g. Kingdon 2003) and are likely to form a major component of adaptation. Indeed, the impacts of the 2008 extreme event during the Spring Festival highlighted important weaknesses in the response to extreme climate events and led policy makers to accelerate the process of formulating contingency response measures for severe meteorological disasters. These include Regulations on Meteorological Disaster Prevention' and 'National Planning on Meteorological Disaster Prevention', aimed at enhancing cooperation among different ministries, establishing mechanisms for information sharing, standardising infrastructure and promoting monitoring and forecasting of meteorological disasters (see http://news.xinhuanet.Com/ politics/2008-02/15/content_7610047.htm, in Chinese).

China's First National Communication to the United Nations Framework Convention on Climate Change was published in 2004 (presented at COP 10, NDRC 2004). Preparation of the Second National Communication began in early 2008 and China's 'National Climate Change Programme' was published in 2007 (NDRC 2007). The Programme recognises mitigation and adaptation as integral components of the strategy to cope with climate change; 'China will take practical measures to enhance its capacity to adapt to climate change via key projects for ecosystem protection, disaster prevention and reduction and other key infrastructure construction'
(NDRC 2007, p. 31). Institutional responsibility for climate change in China sits within the National Development Reform Commission (NDRC) in the Department of Climate Change, established in 2008, which is responsible for analysing the impact of climate change on socio-economic development and organising and coordinating the formulation of key strategies, plans and policies dealing with climate change. The National Leading Group Dealing with Climate Change, established in 2007, is China's national consultation and coordination mechanism to address climate change, including mitigation and adaptation. China's 12th Five Year Plan, published in 2011, is the first to include a full paragraph on adaptation (Xinhuanews: http://news.xinhuanet.com/ politics/2011-03/16/c_121193916.htm, in Chinese).

Research on climate change impacts has a long history in China, with early examples including Impacts of climate change on China's agriculture, forestry, water resources, and sea level rising, and associated response strategies', supported by the Ministry of Science and Technology (MoST) during China's 8th (1991-1995) and 9th (1996-2000) 5 yr planning periods. Another early study was undertaken through the World Wide Fund for Nature (Hulme 1992), and a major study on the effects of climate change on agriculture in China was supported by the Department for Environment, Food and Rural Affairs (Defra), UK (2003-2008) (Lin et al. 2005, Xiong et al. 2008a, 2009a,b). Extensive reviews have been produced such as the recent 'National Climate Change Assessment Report' (EBNCCA 2007), and there is a growing body of literature on impacts across sectors. Research on adaptation and linking of impact projections with decision-making and policy processes, however, is only now emerging (as in many other countries). Early examples include projects supported by MoST, mentioned above, and the 'Research and demonstration of adaptation technologies and measures' also supported by MoST during 2007-2010.

Agriculture possesses special importance for China, with $54 \%$ of its population living in rural areas (NBSC 2009). In 2005, the total increased value of agricultural GDP was 2.27 trillion RMB (US\$ 337 billion; NBSC 1996, 2006), and farmland comprised an estimated 130 million ha (EBCAY 2006). Of this total, irrigated farmland with potentially stable yields comprised $32 \%$ (calculation based on EBCAY 2006). Overall, droughts are responsible for the largest direct economic losses. Average annual grain losses were 14 million tons between 1949 and 2001 and 26 million tons between 1991 and 2000, accounting for 
$4.6 \%$ and $5.4 \%$, respectively, of the production (Liu et al. 2005). In addition to climate hazards, degradation of farmland is a serious problem. An estimated $30 \%$ of farmland in China displays some level of damage due to water and soil erosion, and as much as $40 \%$ of farmland in arid and semiarid regions ( $\mathrm{Li}$ 2000b).

China experiences water scarcity due to the uneven temporal and spatial distribution of water resources and demands upon them. Water resources south of the Yangtze River basin account for more than $80 \%$ of the total, whilst arable land only accounts for $38 \%$ of the total; water resources north of the Huaihe basin (Fig. 1) account for less than $20 \%$ of the total, whilst arable land accounts for $62 \%$ ( $\mathrm{Li}$ 2000b). Water availability is critical for agricultural production in China (Fischer et al. 2007) and is already a major stress factor for grain production, particularly in northern parts of the country (Li 2006). In China, irrigated agriculture accounts for $70 \%$ of total water use (Zhang 2002). More than $75 \%$ of grain production is from irrigated land, and this production is key to achieving national policy targets for food production and poverty alleviation (Wu et al. 2006).

A further dimension to adaptation in agriculture and other sectors is to design and implement sustainable responses, and to link adaptation and mitigation. The agriculture sector is a major emitter of greenhouse gases in China. Much is published on

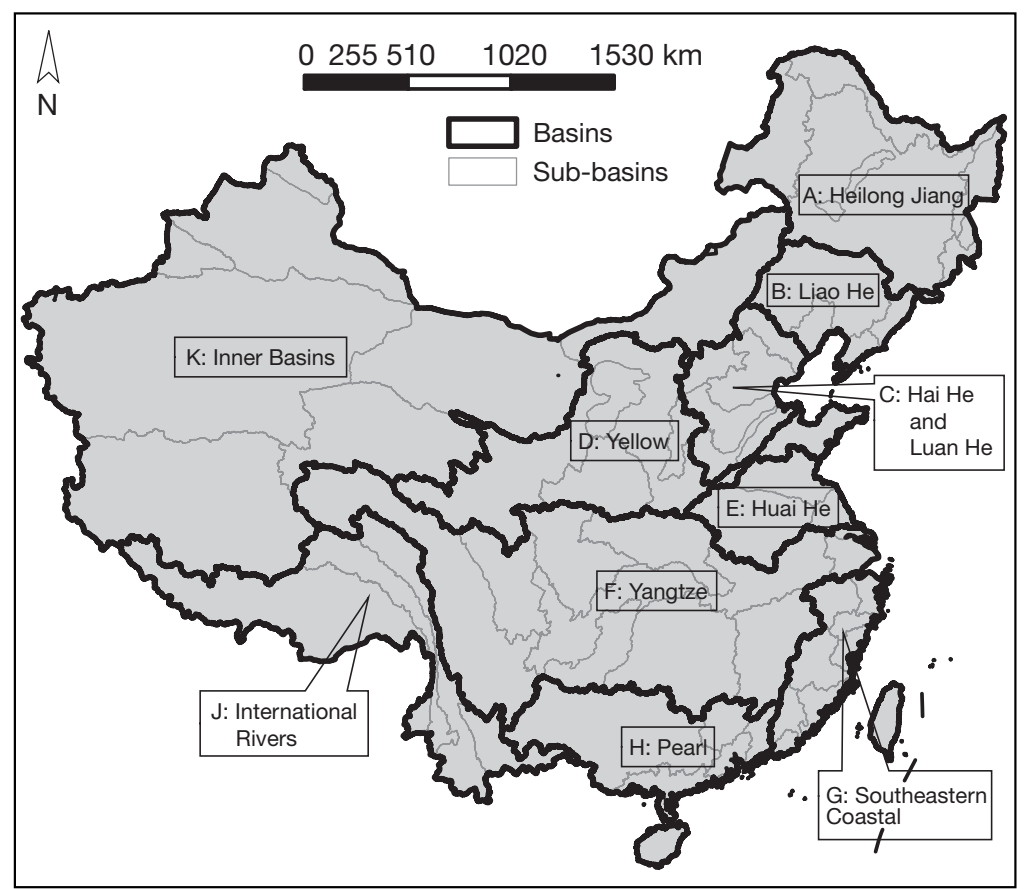

Fig. 1. Main river basins and sub-basins of China emissions from the sector but very little on potential synergies between mitigation and adaptation. A review by Smith \& Olesen (2010) highlighted various areas of adaptation with potential for mitigation and concluded: 'There appears to be a large potential for synergies between mitigation and adaptation within agriculture. The interlinkages between mitigation and adaptation are, however, not very well explored and further studies are warranted' (Smith \& Olesen 2010 , p. 1). This is also the case in the water sector and is underscored by the close interactions between water and energy use for irrigated agriculture (Rothausen \& Conway 2011).

The major environmental and socio-economic challenges that face China's sustainable use of land and water resources and the growing recognition (within and outside government) of the potential for anthropogenic climate change to exacerbate these challenges provide the context to the present review. We use the following understanding of terms in relation to climate: (1) climate trends represent incremental changes in climate parameters over an identified period of time; (2) climate variability refers to the variations around the long-term (generally $30 \mathrm{yr}$ ) average; (3) extreme events represent highly unusual occurrences over the period of record with some flexibility on thresholds of frequency or intensity, to reflect the different practices and terminology used by various government and statistical departments; (4) future climate change includes the effects of anthropogenic influences manifest against background variability due to other factors.

Although many studies of climate change impacts on agriculture have appeared in Chinese publications, these have received limited attention in the international community. The objectives of the present study are therefore to: (1) review the effects of recent climate trends and extreme events in the agriculture sector, (2) outline future climate change projections for China using results from a high-resolution regional climate model (RCM) and the average change across the range of global climate models (GCMs) used in the IPCC Fourth Assessment Report (IPCC 2007a,b), (3) review current understanding of future climate change impacts on agriculture, and (4) identify uncertainties in these studies and highlight important directions for future research. 


\section{RECENT CLIMATE VARIABILITY AND EXTREME EVENTS}

China has experienced noticeable climate variability and trends during the past 100 yr. Box 1 summarises observations of recent climate behaviour, including trends in China from the IPCC AR4 (IPCC $2007 a, b)$. Annual average air temperature has risen by 0.5 to $0.8^{\circ} \mathrm{C}$ during the century (EBNCCA 2007), slightly faster than the average rate of global warming. Most of the temperature rise occurred during the last 50 yr (Ren et al. 2005). Warming was greater in western, eastern and northern China than south of the Yangtze River, while in the southwest, average temperatures have decreased (NCC 2010; Fig. 2). The localised cooling in parts of southwest/southern China may be related to increased emission of pollutants such as $\mathrm{SO}_{2}$ (Li et al. 1995, Hu et al. 2003). Winter temperatures display the most rapid warming.

Annual total precipitation in China shows more complex spatial and temporal patterns during the past $100 \mathrm{yr}$, with considerable differences among provinces (EBNCCA 2007). In western China it increased since the 1920s (Shi 2003). During 19562000, precipitation decreased in the Yellow, Haihe, Liaohe and Huaihe River basins (ranging from 50 to 120 mm; see Fig. 1 for locations) and increased in the lower reaches of the Yangtze River, along the coastal areas in southern China and in northwestern China (ranging from 60 to $130 \mathrm{~mm}$, Ding et al. 2007). Zhai et al. (2005) analysed daily precipitation records from 740 stations and identified distinctive regional and seasonal patterns. In western China, increases occurred in winter and summer, whereas in eastern China there was no consistent pattern. Spring precipitation increased in the south of northeast China and north China but decreased significantly in the midreach of the Yangzte River. The summer monsoon precipitation trend was similar to the annual patterns. Autumn precipitation generally decreased throughout eastern China. In winter, precipitation decreased over the northern part of eastern China but increased in the south.

Fig. 3 shows trends in the number of extreme heavy rain days during the past $53 \mathrm{yr}$. The frequency has increased in southern and northwest China and decreased in other regions (Chen et al. 2010). Sea level rose during the 20th century at a rate of $2.5 \mathrm{~mm} \mathrm{yr}^{-1}$ (SOA 2007), a rate
Box 1. Summary of key findings on recent climate behaviour in China, based on IPCC $(2007 a, b)$

\section{Temperature}

Widespread warming:

- Warmer in the last $50 \mathrm{yr}$, higher extremes

- Increase in frequency of short-duration heat waves in recent decades

- Increasing warmer days and nights in recent decades

\section{Precipitation}

- Complex patterns, increase in intensity

- Some evidence for increase in flood frequency

- Some areas increase in drought (possibly temperature related)

\section{Drought}

- Increase in area affected by drought has exceeded 6.7 M ha since 2000 in Beijing, Hebei Province, Shanxi Province, Inner Mongolia and North China

- Increase in dust-storm-affected areas

Floods

- Increasing frequency of extreme rains in western and southern parts including Yangtze River, and decrease in northern regions

- More floods in Yangtze River in past decade

- More frequent floods in northeast China since 1990s

- More intense summer rains in east China; severe flood in 1999

- Seven-fold increase in frequency of floods since 1950s

Other

Cyclones

- Number and intensity of strong cyclones increased since 1950s

- 21 extreme storm surges in 1950-2004, of which 14 occurred during 1986-2004

- Some glaciers retreating

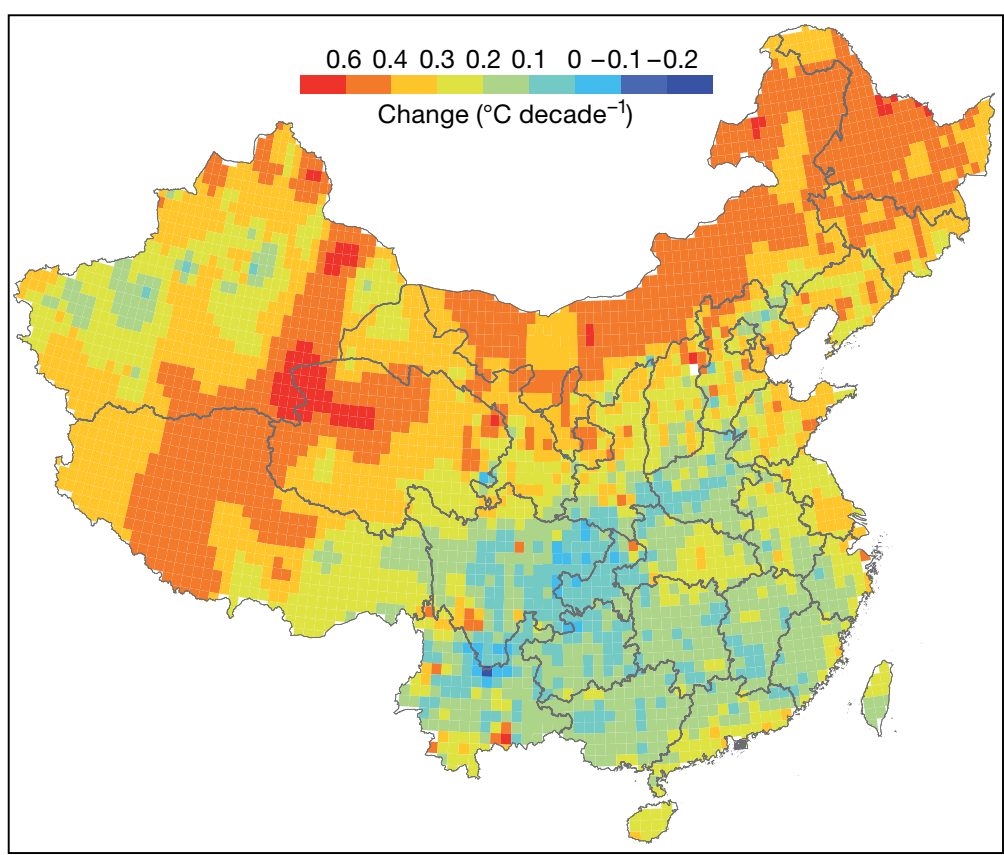

Fig. 2. Temperature trends during 1961-2009 (data from NCC 2010) 


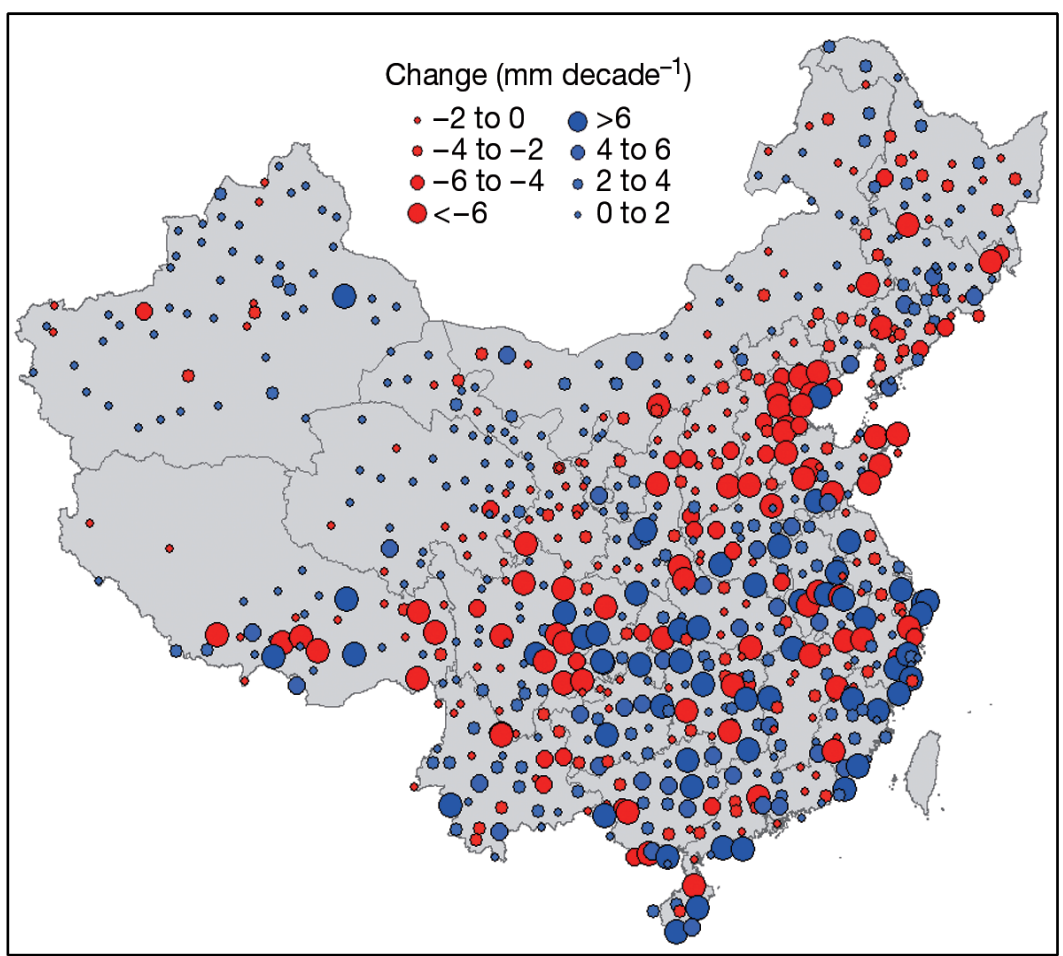

Fig. 3. Trends in highest daily precipitation during 1956-2008 (data from Chen et al. 2010). Blue: increase, red: decrease slightly higher than the global average of $1.7 \mathrm{~mm} \mathrm{yr}^{-1}$ (IPCC 2007a). Glaciers in China show complex patterns with a tendency for retreat during the past $100 \mathrm{yr}$, with a recent acceleration in the rate (EBNCCA 2007). A recent review showed that climate warming is not uniform across the Himalayan region and that although the main trend in most of High Asia does seem to be glacial retreat, it is occurring at very different rates in different mountain ranges, even within the same mountains (Hewitt 2010).

\section{PROJECTIONS OF FUTURE CLIMATE CHANGE}

Global and regional climate models, forced by different greenhouse gas (GHG) emission scenarios, have been widely used to project climate change to 2100 (Christensen et al. 2007). Table 1 presents an overview

Table 1. Projections of climate and associated variables, ranked subjectively in decreasing order of confidence (adapted and updated from IPCC 2001 with new results and IPCC 2007a,b)

\begin{tabular}{|c|c|c|}
\hline Confidence & Climate variable & Changes in China \\
\hline \multirow[t]{8}{*}{ High } & Atmospheric $\mathrm{CO}_{2}$ concentration & As IPCC SRES A2 and B2 emissions \\
\hline & Global mean sea level & See IPCC AR4 \\
\hline & Global mean temperature & See IPCC AR4 \\
\hline & Regional seasonal temperature & China warms by: \\
\hline & & 2020s, A2: $1.3^{\circ} \mathrm{C}, \mathrm{B} 1: 1.2^{\circ} \mathrm{C}$ (Xiong et al. 2008a) \\
\hline & & $\begin{array}{l}\text { 2050s, A2: } 2.4^{\circ} \mathrm{C}, \mathrm{B} 1: 1.9^{\circ} \mathrm{C} \text { (Xiong et al. 2008a) (Average of } 23 \\
\text { climate models) }\end{array}$ \\
\hline & & $\begin{array}{l}\text { Warming is most rapid in the north and west and slowest in the } \\
\text { south }\end{array}$ \\
\hline & Regional temperature extremes & $\begin{array}{l}\text { Higher maximum temperatures, longer growing season (based } \\
\text { on temperature) }\end{array}$ \\
\hline \multirow[t]{2}{*}{ Medium-high } & Regional precipitation & $\begin{array}{l}\text { Across China precipitation generally shows modest increases, } \\
\text { up to } \sim 10 \% \text { by the } 2080 \mathrm{~s}\end{array}$ \\
\hline & Regional seasonal precipitation & $\begin{array}{l}\text { Precipitation tends to increase in the west, north and northeast, } \\
\text { slight decreases in the south and east }\end{array}$ \\
\hline \multirow[t]{2}{*}{ Medium } & Precipitation extremes & Daily extreme precipitation amounts likely to increase \\
\hline & $\begin{array}{l}\text { Regional potential } \\
\text { evapotranspiration }\end{array}$ & $\begin{array}{l}\text { Higher temperatures could lead to higher rates of evaporation } \\
\text { and, assuming other influences remain unchanged, higher rates } \\
\text { of surface water evaporation and higher soil moisture deficits }\end{array}$ \\
\hline Low & $\begin{array}{l}\text { Changes in other extremes } \\
\text { (e.g. cyclones) }\end{array}$ & See IPCC AR4 \\
\hline $\begin{array}{l}\text { Very low or } \\
\text { Unknown }\end{array}$ & $\begin{array}{l}\text { Climate surprises (e.g. disintegration } \\
\text { of the West Antarctic Ice Sheet) }\end{array}$ & $\begin{array}{l}\text { Examples for China could include rapid glacial melt in the west, } \\
\text { rapid changes to permafrost }\end{array}$ \\
\hline
\end{tabular}


of key climate variables and their projections in China. Details of their derivation and explanation of the main sources of uncertainty can be found in IPCC $(2007 a, b)$. All climate models simulate continued and more rapid warming in China. Most models simulate increasing precipitation, but there are differences among climate models, especially in spatial patterns. Xiong et al. (2009a) presented projections of future temperature and precipitation for China based on average values from the suite of GCMs used for the IPCC Fourth Assessment Report (Meehl et al. 2007). They defined four $30 \mathrm{yr}$ periods for analysis: 1961-1990 (baseline), 2010-2039 (2020s), 2040-2069 (2050s) and 2070-2099 (2080s) under 2 GHG emission scenarios to show the general direction of change averaged for all of China and 5 sub-regions. No judgement was made on the models' performance, and results were presented with equal weight for all models, except for 1 outlier which was excluded from the analysis (Xiong et al. 2009a). The main results are summarised in Box 2 and Figs. 4 \& 5.

RCMs provide greater spatial detail and generally improved simulation of important circulation processes and the effects of surface features such as lakes and mountains (Wilby et al. 2009), although they are still limited by the underlying biases in the boundary conditions from the GCM. Xu et al. (2005) used the Hadley Centre RCM system PRECIS to analyse the changes of temperature and precipitation over China under SRES A2 and B2 scenarios in different time slices in the 21st century. Fig. 6 shows the multi-model results for A2 emissions, with 30 yr average changes in temperature plotted against changes in precipitation for all models, including PRECIS from Xu et al. (2005), and 3 future time slices. Climate scenarios from PRECIS show warming similar to the allmodel average, but PRECIS produces wetter conditions than the multi-model average for China. H. L. Yang et al. (2010) looked at the effects of the PRECIS scenarios on heat wave occurrence, and found that western, northwest and northeast China are projected to have more heat waves by the 2080s.

Zhang et al. (2006) used the output from HadCM3 to analyse future changes in precipitation extremes over China under SRES B2 scenarios relative to a baseline from 1961-1990. They found an increasing trend for heavy rain events over China except in the northeast and southern parts. Heavy rain events $\left(\geq 50 \mathrm{~mm} \mathrm{~d}^{-1}\right)$ mostly decreased in the west and increased in the east.

\section{IMPACTS ON AGRICULTURE}

\subsection{Extreme events}

Agriculture is one of the sectors most affected by natural hazards. Droughts, floods, low temperature stress and hail constitute the major hazards that affect China's agriculture (Zhang 1991). These hazards show distinct regional characteristics across China (Ruan 2000) and are responsible for $71 \%$ of the losses caused by natural hazards annually (Huang et al. 2005). Between 1996 and 2003, average annual grain loss from meteorological hazards was 50.9 million tons, compared with total annual grain production of 472.9 million tons during the same period (NBSC 1997, 2004), and average annual direct economic losses were 110.5 billion RMB (US\$ 16.4 billion) during 1996-2003 (Table 2, D. Wang et al. 2006). Over the previous $10 \mathrm{yr}$, the annual direct economic effects of crop loss due to meteorological hazards were roughly 1 to $3 \%$ of the national GDP (CMA 2006). The increased value of agricultural GDP accounted for $16.2 \%$ of total GDP during the period 1996-2005 (NBSC 1997, 2006). Provincial and local scale effects are substantial in terms of economic and social impact; for instance, per capita income of farmers fell by $200 \mathrm{RMB}$ due to the effects of extreme events on crops and animal husbandry in Hunan Province during 1998-2003 (D. Wang et al. 2006a), accounting for roughly $9 \%$ of the average per capita income during the same period. Zhang (1999) concluded that if economic losses induced by drought and flooding increased by $10 \%$, poverty rates (defined by basic food requirements and costs) in rural areas in China could increase by 2 to $3 \%$.

\subsection{Drought}

Based on data from 606 weather stations, during 1951-2008, China as a whole showed a weak increasing trend in the area experiencing drought. Most northern river basins experienced an increase in drought area, particularly the Songhuajiang, Liaohe and Haihe River basins. Severe and prolonged droughts occurred in areas of the Liaohe, Haihe and Yellow River basins during the late 1990s to the early 2000s. There were no significant long-term changes in most of the river basins of southern China, except for the southwest (Zou et al. 2010). Based on analyses of data from 1996-2005, most regions of China experienced drought in some form. However, the Huanghe and Huaihe basins (Fig. 1) account for 
Box 2. Key results from climate multi-models for China and sub-regions (adapted from Xiong et al. 2008a). See Figs. 4 \& 5

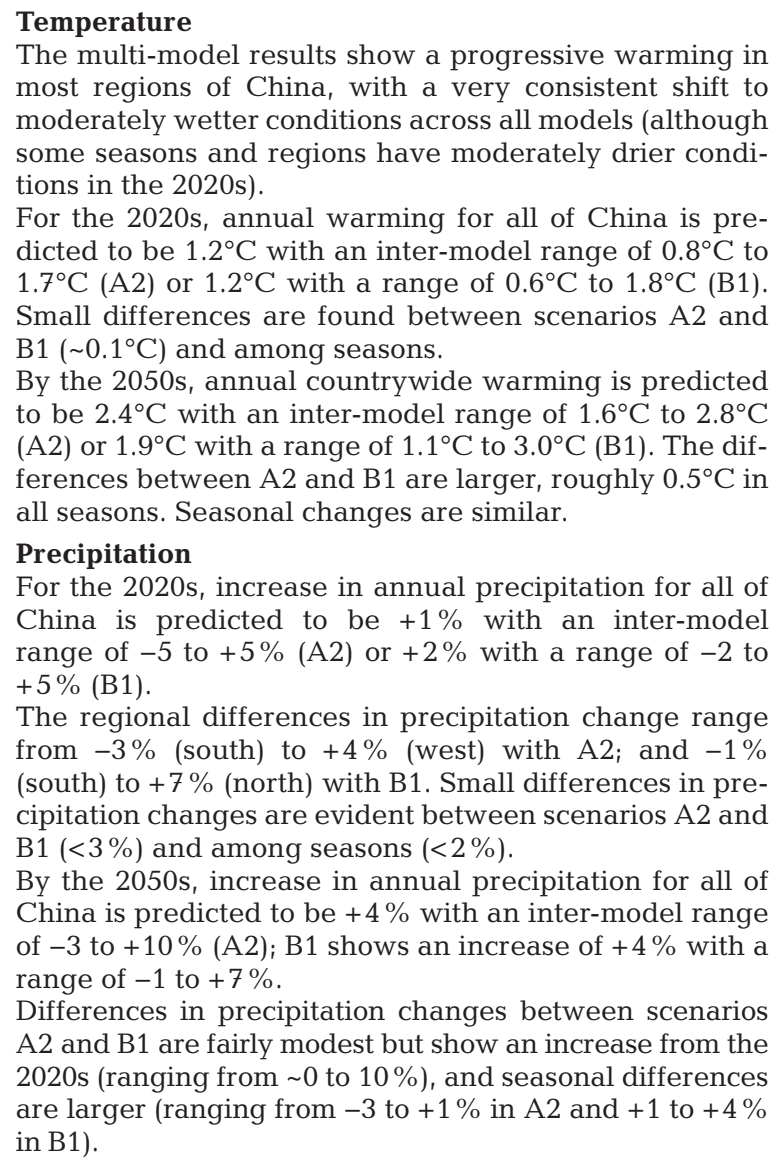

By the 2050s, annual countrywide warming is predicted to be $2.4^{\circ} \mathrm{C}$ with an inter-model range of $1.6^{\circ} \mathrm{C}$ to $2.8^{\circ} \mathrm{C}$ (A2) or $1.9^{\circ} \mathrm{C}$ with a range of $1.1^{\circ} \mathrm{C}$ to $3.0^{\circ} \mathrm{C}$ (B1). The differences between $\mathrm{A} 2$ and $\mathrm{B} 1$ are larger, roughly $0.5^{\circ} \mathrm{C}$ in all seasons. Seasonal changes are similar.

\section{Precipitation}

For the 2020s, increase in annual precipitation for all of China is predicted to be $+1 \%$ with an inter-model range of -5 to $+5 \%$ (A2) or $+2 \%$ with a range of -2 to $+5 \%(\mathrm{~B} 1)$.

The regional differences in precipitation change range from $-3 \%$ (south) to $+4 \%$ (west) with $\mathrm{A} 2$; and $-1 \%$ (south) to $+7 \%$ (north) with B1. Small differences in precipitation changes are evident between scenarios A2 and B1 $(<3 \%)$ and among seasons $(<2 \%)$.

By the 2050s, increase in annual precipitation for all of China is predicted to be $+4 \%$ with an inter-model range of -3 to $+10 \%$ (A2); B1 shows an increase of $+4 \%$ with a range of -1 to $+7 \%$.

Differences in precipitation changes between scenarios A2 and B1 are fairly modest but show an increase from the 2020s (ranging from $\sim 0$ to $10 \%$ ), and seasonal differences are larger (ranging from -3 to $+1 \%$ in $\mathrm{A} 2$ and +1 to $+4 \%$ in B1).

roughly $43 \%$ of the drought-affected area nationally. The northeast accounts for $20 \%$, and the lower and middle reaches of the Yangtze River also frequently experience drought. Together these 3 regions account for $79 \%$ of the drought-affected areas. Given its size, local or regional droughts occur somewhere in China in most years. Droughts have become more serious in $77 \%$ of provinces and in most of the provinces located north of the Yangtze River. Drought had become less serious or remained unchanged in the provinces south of the Yangtze River during 1949-2000 (J. Wang et al. 2006), although the recent drought may reverse this situation (Qiu 2010).

Droughts cause over half of the grain losses that result from meteorological hazards (Li 2000a, D. Wang et al. 2006). During the period between 1978 and 2004, the area of cropland affected by drought averaged 13.9 million ha $\mathrm{yr}^{-1}$ (EBCAY 2005; Fig. 7). Since the 1990s, losses caused by drought have risen sharply. From 1950 to 1970, grain loss in absolute terms due to drought was less because of the lower

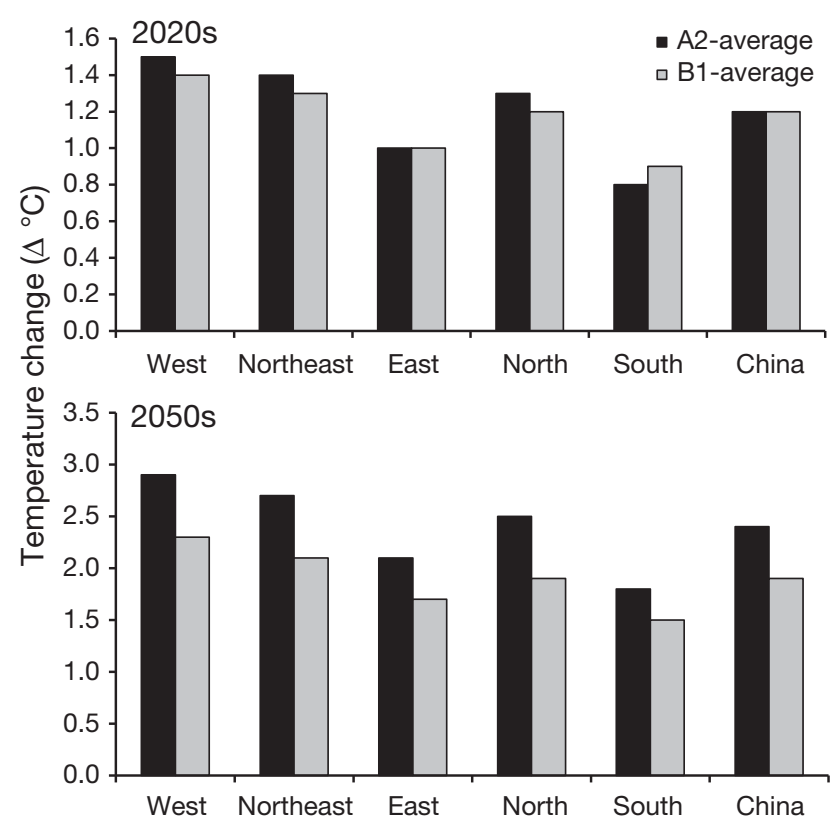

Fig. 4. Multi-climate model average change in annual temperature $\left({ }^{\circ} \mathrm{C}\right)$ for all of China and sub-regions under SRES $\mathrm{A} 2$ and $\mathrm{B} 1$ emission scenarios

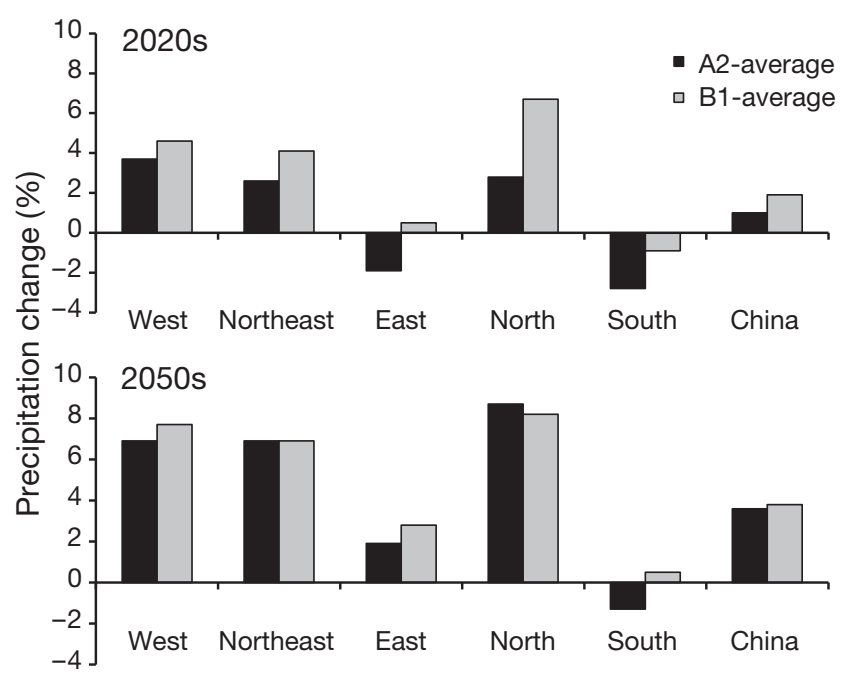

Fig. 5. Multi-climate model average change in annual precipitation (\%) for all of China and sub-regions under SRES A2 and B1 emission scenarios. Upper panel: 2020s, lower panel: 2050s

total grain production. In the $1980 \mathrm{~s}$, however, grain losses rose to an average of 19.2 million tons $\mathrm{yr}^{-1}$ and by the 1990 s they were 28.2 million tons (D. Wang et al. 2006), with economic losses of 34.5 billion Yuan RMB (at price values for 2000, US\$ 5.1 billion; Liu et al. 2005). Fig. 8 shows the economic losses from reduced grain production for the period 1986-2001 with an increase in sensitivity of high-yield grain production to drought over time (Liu et al. 2005). 


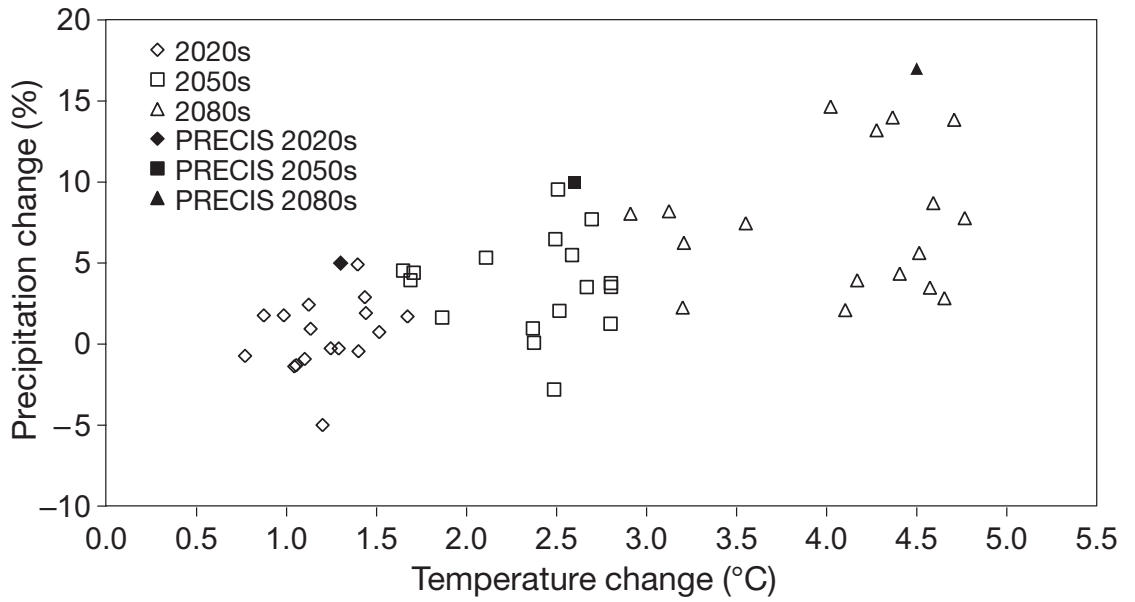

Fig. 6. Annual changes in temperature and rainfall by the 2020s, 2050s and 2080s with 17 global climate models from IPCC AR4 and PRECIS (A2 scenario) averaged for all of China

Table 2. Grain and economic losses from meteorological hazards in China

\begin{tabular}{|c|c|c|c|c|c|c|}
\hline \multirow{2}{*}{ Year } & \multirow{2}{*}{$\begin{array}{l}\text { Affected } \\
\text { area } \\
\left(10^{6} \mathrm{ha}\right)\end{array}$} & \multirow{2}{*}{$\begin{array}{l}\text { Damaged } \\
\text { areas } \\
\left(10^{6} \mathrm{ha}\right)\end{array}$} & \multirow{2}{*}{$\begin{array}{l}\text { Cropland with } \\
\text { no harvest } \\
\left(10^{6} \mathrm{ha}\right)\end{array}$} & \multicolumn{2}{|c|}{ _Losses } & \multirow[t]{2}{*}{ Source } \\
\hline & & & & $\begin{array}{l}\text { Grain } \\
\left(10^{6} \mathrm{t}\right)\end{array}$ & $\begin{array}{c}\text { Other } \\
\text { (billion Yuan) }\end{array}$ & \\
\hline 1996 & 47.0 & 21.2 & 5.4 & 20.0 & - & Wang et al. (2006a) \\
\hline 1997 & 53.4 & 30.3 & 6.4 & 74.4 & 98.0 & Wang et al. (2006a) \\
\hline 1998 & 50.1 & 25.2 & 7.6 & 30.0 & 140.0 & Wang et al. (2006a) \\
\hline 1999 & 50.0 & 26.7 & 6.8 & 35.0 & - & Wang et al. (2006a) \\
\hline 2000 & 54.7 & 34.4 & 10.2 & 77.9 & 100.0 & Wang et al. (2006a) \\
\hline 2001 & 52.2 & 31.8 & 8.2 & 70.3 & 100.0 & Wang et al. (2006a) \\
\hline 2002 & 57.1 & 27.3 & 6.6 & 45.8 & 93.0 & Wang et al. (2006a) \\
\hline 2003 & 54.7 & 32.7 & 8.5 & 54.0 & 132.0 & Wang et al. (2006a) \\
\hline 2004 & 37.1 & 16.3 & 4.3 & & 156.6 & NBSC (2005) \\
\hline 2005 & 38.8 & 20.0 & 4.6 & & 210.1 & EBCAY $(2006,2007)$ \\
\hline 2006 & 41.1 & 24.6 & 5.4 & & 250.0 & EBCAY $(2006,2007)$ \\
\hline
\end{tabular}

Drought is also associated with human and animal suffering, particularly by reducing the availability of drinking water. Access to potable water remains an important issue, in rural areas, and 400 cities of a total of 669 have suffered from water shortages (Wang 2006). In a normal year, the total water shortage nationwide is nearly 40 billion $\mathrm{m}^{3}$, but in northern China, the situation is even worse (Wang 2006). The average economic loss caused by drought was

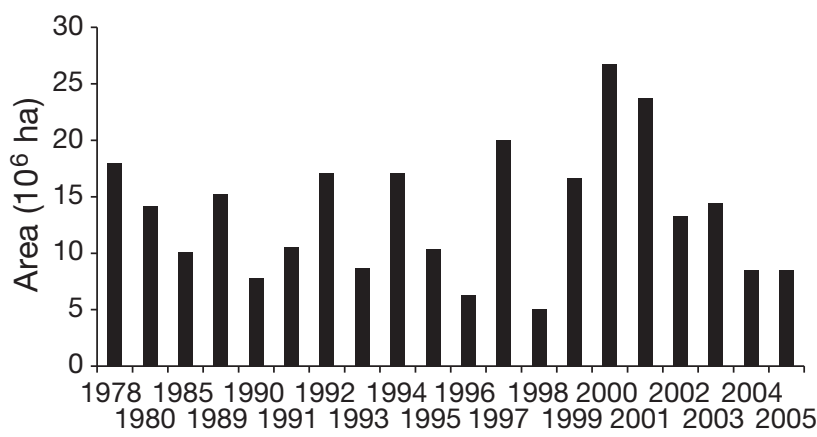

Fig. 7. Cropland area damaged by drought in China (source: EBCAY 2005)
36.7 billion Yuan RMB (US\$ 5.4 billion) per year in 2000-2005 (MoWR 2001-2005). Table 3 shows the population affected by drought-induced drinking water shortages between 1991 and 2001 (Liu et al. 2005). Farmers' net incomes are impacted by drought with annual per capita economic losses from reduced grain production of 37 Yuan RMB (US\$ 5.5), roughly $4.1 \%$ of farmers' average income from agricultural

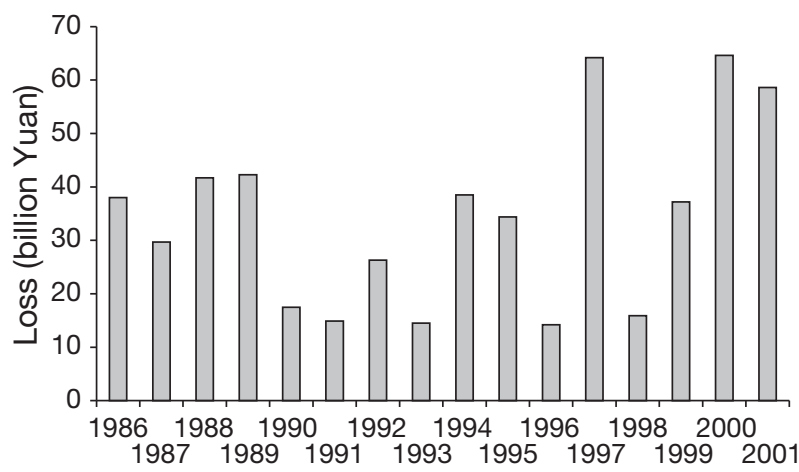

Fig. 8. Economic losses from reduced grain production due to drought during the period 1986-2001 (source: Liu et al. 2005) 
sources, between 1985 and 2001 (data on farmers' income: DRS 2005). Farmers in the northeast and north of China tend to be most affected by drought in terms of economic losses, with a per capita loss of 100 Yuan RMB (US\$ 14.8) in the northeast and 71 Yuan RMB (US\$ 10.5) in the north of China during 1985-2001. Income from growing crops remains a major component of total income for many farmers, although this is changing rapidly. In areas of northwest China, drought can push farmers back into poverty (Liu et al. 2005), and a recent drought (20042006, Ningxia) had substantial negative consequences across mixed irrigation/grazing and rain-fed farming communities (Li et al. 2008).

\subsection{Floods}

Flood events also disrupt agriculture, particularly in the lower and middle reaches of the Yangtze River, Yellow River and Haihe Plains, and represent the second most damaging meteorological hazard for agriculture. Floods accounted for $28 \%$ of the total economic losses due to meteorological disasters during 2004-2009 (CMA 2005-2010). Between 1950 and 1998, flooding in China produced a total loss of life of 259 000, damaged 110 million houses and affected (or damaged) 9.1 (5.1) million ha of agricultural land per year, which amounts to $10 \%$ and $5 \%$ of the total cropland area, respectively (Table 4). During the late 1980s, the frequency of flood events increased, and by the 1990s major flood events occurred roughly once every 2 yr, with an increasing trend (Zhao et al. 2004).

\subsection{Other hazards}

The two regions most susceptible to damage from spring and winter low temperature stress are the

Table 3. Number of people and domestic animals affected by rural drinking water shortage caused by droughts. Data from Liu (2005)

\begin{tabular}{|ccc|}
\hline Year & $\begin{array}{c}\text { Humans } \\
\left(10^{6} \text { persons }\right)\end{array}$ & $\begin{array}{c}\text { Animals } \\
\left(10^{6} \text { heads }\right)\end{array}$ \\
\hline 1991 & 43.6 & 62.5 \\
1992 & 72.9 & 35.3 \\
1993 & 35.0 & 19.8 \\
1994 & 50.3 & 60.1 \\
1995 & 18.0 & 1.4 \\
1997 & 16.8 & 8.5 \\
1999 & 19.2 & 14.5 \\
2000 & 27.7 & 17.0 \\
2001 & 33.0 & 22.0 \\
\hline
\end{tabular}

Yangtze valley and southern China, and summer low temperature stress mostly affects northeastern China. Over a 28 yr period (1953-1980), the lower and middle reaches of the Yangtze and upland areas of Nanling recorded roughly 20 such events. The most affected crops were winter wheat, oilseed rape, green manure plants and subtropical fruit trees that are vulnerable to cold (CAAS 1999). The mid-part of northeast China and the northeast part of northwest China recorded 25 to 30 such events over the same period, with winter-wheat-growing areas the most affected. China also experiences a range of other major meteorological hazards, including hail, dry hot wind and high temperature stress for rice. A summary of the main geographic regions and crops frequently affected by meteorological hazards is presented in Table 5 (Liu et al. 2003).

\subsection{Recent warming}

Warming across China during recent decades (see Section 2) is the most pronounced and spatially homogenous climate trend for China. Various studies have analysed the effects of this trend on crop production and more widely in the agriculture sector. The warming and lengthening of the growing season has a notable impact on cropping systems; however, the results show complex patterns and highlight the challenge of untangling climate and crop yield/production relationships across diverse agro-ecological conditions, crop types and rapidly changing management and socio-economic conditions of production. For example, Tao et al. (2008) made a detailed study of climate-yield relationships in China at provincial scales and discussed response mechanisms underlying the observed climate-yield relationships. Warming had positive or negative impacts on yield, depending on whether the current temperature was lower (e.g. parts of northern China) or higher (e.g. Guizhou, southern China) than the

Table 4. Flood damages in China between 1950 and 1998. Data from Zhao et al. (2004)

\begin{tabular}{|c|c|c|c|c|}
\hline \multirow[t]{2}{*}{ Period } & \multicolumn{4}{|c|}{ Annual damages } \\
\hline & $\begin{array}{c}\text { Death } \\
\text { toll } \\
\text { (persons) }\end{array}$ & $\begin{array}{c}\text { Houses } \\
\text { collapsed } \\
\left(10^{6}\right)\end{array}$ & $\begin{array}{l}\text { Cropland } \\
\text { affected } \\
\left(10^{6} \text { ha }\right)\end{array}$ & $\begin{array}{c}\text { Cropland } \\
\text { damaged } \\
\left(10^{6} \text { ha }\right)\end{array}$ \\
\hline 1950-1959 & 8571 & 2.41 & 7.36 & 4.56 \\
\hline 1960-1969 & 4091 & 2.51 & 7.67 & 4.73 \\
\hline 1970-1979 & 5179 & 1.23 & 5.36 & 2.29 \\
\hline 1980-1989 & 4349 & 1.54 & 10.43 & 5.52 \\
\hline 1990-1998 & 4193 & 3.44 & 15.45 & 8.68 \\
\hline
\end{tabular}


Table 5. Distribution of crops affected by the major meteorological hazard types in China. Data from Liu et al. (2003)

\begin{tabular}{|c|c|c|}
\hline Hazards & Regions & Crops \\
\hline Drought & $\begin{array}{l}\text { Nationwide, severe spring droughts in north, } \\
\text { and summer droughts across Yangtze River } \\
\text { basin, Jiangnan and Jianghua }\end{array}$ & $\begin{array}{l}\text { Rice, wheat, corn, soybean, cotton, timber, fruit } \\
\text { trees }\end{array}$ \\
\hline Floods & $\begin{array}{l}\text { Middle and lower reaches of Yangtze River, } \\
\text { south, north and northeast }\end{array}$ & Rice, wheat, rape, corn, soybean, sorghum, millet \\
\hline \multirow[t]{4}{*}{ Low temperature } & $\begin{array}{l}\text { Summer low temperature: Heilongjiang, Jilin, } \\
\text { Liaoning, Inner Mongolia, Ningxia and Hebei }\end{array}$ & Corn, rice, wheat, soybean, sorghum, millet \\
\hline & $\begin{array}{l}\text { Autumn low temperature: Yangtze River basin, } \\
\text { and south }\end{array}$ & Late and double-harvest rice \\
\hline & Winter low temperature: south & Lichee, longan, mango, banana, tropical cash crops \\
\hline & $\begin{array}{l}\text { Unusually cold spell in an otherwise warm } \\
\text { early spring: Yangtze River basin, and north }\end{array}$ & Rice \\
\hline Frostbite & $\begin{array}{l}\text { Northwest, north, northeast, mid-south and } \\
\text { south }\end{array}$ & $\begin{array}{l}\text { Winter wheat, cotton, corn, rice, sweet potato, } \\
\text { sorghum, vegetables, fruits }\end{array}$ \\
\hline Cold injury & Northwest, north, east and mid-south & $\begin{array}{l}\text { Winter wheat, rape, vegetables, grape, orange, tea, } \\
\text { fruits }\end{array}$ \\
\hline Hail & $\begin{array}{l}\text { Nationwide, more in Qinghai-Tibet Plateau, } \\
\text { and Qilian Mountains }\end{array}$ & $\begin{array}{l}\text { Crops, trees and stock grown in summer and } \\
\text { autumn }\end{array}$ \\
\hline Dry hot wind & $\begin{array}{l}\text { Henan, Hebei, Shandong, Anhui, Shanxi, } \\
\text { Shan'xi, Ningxia, south of Jiangsu, Hexi Corri- } \\
\text { dor of Gansu and Tulufan basin in Xinjiang }\end{array}$ & Wheat \\
\hline High temperature & $\begin{array}{l}\text { Middle and lower reaches of Yangtze River } \\
\text { and south }\end{array}$ & Early and mid-season rice \\
\hline
\end{tabular}

optimum temperature for yield. In some cases, a small increase in temperature had a large effect on crop yield. Precipitation also had complex effects on yield, for example, a negative relationship with rice and wheat yield in the south (yield loss from disease, pest and root problems) and a positive relationship with maize and soybean yield in north and northeast China (moisture stress in rain-fed crops; Tao et al. 2008).

Examples exist where mild winters have led to earlier onset of budding and flowering in winter wheat and some trees and fruits, a change in planting from early- to late-maturing varieties and a northward shift in the planting boundary. This has made crops more vulnerable to cold and has led to an increase in crop damage due to spring frost (Fang et al. 2005, Zhao et al. 2009).

Some aspects of recent warming have been beneficial (Yang et al. 2007). Warming during the past 3 decades has contributed to the expansion of winter wheat in northeast China (Gong 1995, Sun 1997, Yang et al. 2000, Wang et al. 2003, Yang et al. 2007), the area of maize has expanded northwards and eastwards (Zhao et al. 2009), and double rice cropping has expanded northwards (X. Yang et al. 2010). Song et al. (2010) identified an extension of the growing season by more than $10 \mathrm{~d}$ in some regions of northeast China between 1951 and 2007. Liu et al. (2009) found northward displacement in the accu- mulated temperature isoline in this area during 1961-2007. In the southern part of northeast China, double cropping systems have replaced single cropping systems, leading to higher overall crop yields. Certain varieties of maize that have a relatively long growth period and high yield have been grown more widely in Jilin Province, northeast China, resulting in increased output. The northern boundary of areas currently under multiple cropping is likely to move farther north as well as westwards (Zhang 2000). Dong et al. (2009) analysed the spatial patterns of annual accumulated temperatures (days $>10^{\circ} \mathrm{C}$ ) and found an increase since the late $1980 \mathrm{~s}$, with $3.6 \times 10^{5}$ $\mathrm{km}^{2}$ of land shifting in ideal suitability from spring to winter wheat zones.

Depending on the timing of the warming, e.g. during certain periods with critical phenological events such as flowering, crop yields can be adversely affected. In southern China, where high temperatures mean that crops already grow close to their limits, warming is more likely to reduce yields. Lu et al. (2008) used a phenological simulation model, validated using sowing-date experiments, to simulate developmental stages in rice growth in southern China. Driving their model with the observed warming during 1951-2006 reduced the length of the growing season by 6 to $14 \mathrm{~d}$ in the Yunnan-Guizhou Plateau and by 1 to $2 \mathrm{~d}$ in most of the low plain areas of southern China. 


\section{ASSESSMENT METHODS}

Studies of climate change impacts on crops in China show a wide range of results, reflecting, among other things, differences among GCM projections (e.g. temperature, precipitation), the methods used to assess impacts (e.g. crop models), and whether or not and how the effects of $\mathrm{CO}_{2}$ fertilisation are included. The spatial and temporal scale of analysis is also important: some studies focus on nationally aggregated impacts which may obscure differences at provincial levels, and some focus on the near-term future, whereas others project to the end of the century. Different crops and cultivars exhibit varying sensitivities to a wide range of climatic factors conditioned upon an even wider range of non-climate interacting factors such as soil type, management, pests and disease, $\mathrm{CO}_{2}$, etc. Most crop impact studies only consider climate change and $\mathrm{CO}_{2}$ fertilisation, while other factors, such as incremental adaptation measures, technology improvement, and in cases of irrigated agriculture, increasing demand for water from other sectors, are neglected. Studies also tend to focus on changes in average climate conditions rather than the effects of changes in the nature of extreme events.

Climate change may also affect the quality of grain. Elevated $\mathrm{CO}_{2}$ levels may cause a decrease in the quality of wheat due to a decrease in protein content. At a doubled $\mathrm{CO}_{2}$ concentration, the contents of lysine and protein in soybean, winter wheat and maize decrease (Gao \& Wang 1994, Wang et al. 2000, Bai et al. 2004). $\mathrm{CO}_{2}$ levels also affect stomatal conductance and hence the rate of transpiration and crop water use, but these interactions are only crudely simulated in most models. Finally, surface ozone has largely been absent from impact studies, but is likely to play an increasing role in affecting crop yields, as sources of its precursors increase in China; 'Studies suggest large enhancements in surface ozone over SE Asia....over the next 50 years under projected emissions and climate changes' (Royal Society 2005, cited by Challinor et al. 2009).

Predictions of crop yield response to a given climate stress can also depend on the methodology. The most common approaches for assessing impacts have been econometric or Ricardian models, empirical relationships based on observations and processbased crop growth simulation models. Whilst most crop climate impacts studies for China have used process-based simulation models to estimate changes in yield, there are a few examples of econometric and empirical climate-yield studies. The following sec- tions present results from such studies in China and illustrate some of the challenges to making reliable policy-relevant predictions of climate change impacts.

\subsection{Econometric (Ricardian) studies}

The Ricardian model (see Mendelsohn et al. 1994, cited by Wang et al. 2009) assumes that each farmer maximises income by choosing crops and inputs given a set of variables including inputs, labour, capital climate, irrigation, soil and input prices. The function aims to capture the locus of maximum profit for a range of temperature or precipitation levels, for different crops; as farmers are expected to choose the most profitable crops for different conditions, this method is assumed to capture adaptation. The method explains some variation in land value or net revenue per unit area of land in many different countries. Temperature and precipitation both appear to influence land value and net revenue, but to varying extents. The method does not take into account price changes (see Cline 1996, cited by Wang et al. 2009) and some other farm level factors such as availability of irrigation water, nor does it simulate any biophysical processes, effects of interannual variability or factors such as $\mathrm{CO}_{2}$ fertilisation or interactions with pests.

Ricardian analysis of the role of increasing temperature in farm revenues has shown both negative (Wang et al. 2009) and positive effects on average farm net revenues (Liu et al. 2004). Wang et al. (2009) proposed that the difference between the two studies is due to the choice of data sets, but they noted that both studies found precipitation to have positive effects, and climate effects were generally nonlinear. These contrasting results suggest a need for more detailed analysis of the factors driving crop yield and farm revenue with greater spatial and temporal disaggregation.

\subsection{Empirical methods: climate-yield relationships}

Exploring the observed relationship between climate and crop yields can provide useful insights into sensitivities and can improve the empirical evidence to support predictive modelling. However, reliable estimates of crop yield can be difficult to make and scale up from the plot scale. Data suffer quality problems in many countries, particularly at local levels, due to collection methods, and also contain other sources of production variability such as pests, poor inputs and floods, which can mask climate signals. Lobell et al. 
(2008) presented relationships between observed harvests and monthly temperature and precipitation for many regions, including China. Relationships were significant $\left(\mathrm{R}^{2}>0.14,14 \%\right.$ of the variance in yield) in only 2 out of 7 cases for China. Lobell et al. (2008) obtained probability distributions of production changes using multi-model output (20 GCMs) for 2030 which showed median changes of less than $5 \%$ for all crops (groundnut, soya bean, sugarcane, potato, maize, rice and wheat), with 2 showing slight decreases (maize, rice) and the others showing slight increases.

Tao et al. (2008) made a detailed study of climateyield relationships in China at provincial scales, assessing observed relationships and, where significant, multiplying by sown areas to estimate crop production changes due to climate trends over the period 1979-2002. Year to year changes in 4 crops (rice, wheat, maize and soybean) and 4 climate variables (maximum and minimum temperature, diurnal temperature range and precipitation) were considered. They obtained significant relationships between at least 1 of the climate variables and rice yield in 12 provinces (of 23 which grow rice), wheat yield in 11 (26), maize in 14 (22) and soybean yield in 10 (16). Tao et al. (2008) estimated that the combined effects of growing season climate trends during 1951-2002 led to increases in total production of rice $\left(3.2 \times 10^{5} \mathrm{t}\right.$ decade $\left.^{-1}\right)$ and soybean $\left(0.7 \times 10^{5} \mathrm{t} \mathrm{decade}^{-1}\right)$ and decreases in wheat $\left(-1.2 \times 10^{5} \mathrm{t} \mathrm{decade}^{-1}\right)$ and maize $\left(-21.2 \times 10^{5} \mathrm{t}\right.$ decade $\left.^{-1}\right)$. They found contrasting results across provinces, with maize being most sensitive to trends in maximum temperature and precipitation, and rice, wheat and soybean more affected by minimum temperature. A $1^{\circ} \mathrm{C}$ change in Tmax or Tmin resulted in changes of 11 to $19 \%$ in crop yield, depending on crop and region. Tao et al. (2008) concluded that further research into crop response mechanisms is necessary.

Fraser et al. (2008) explored climate-yield interactions in drought-sensitive regions of East China. They noted that ' ...there are few empirical studies or predictive models that quantify the reasons why harvests may or may not be sensitive to changes in environmental conditions' (Fraser et al. 2008, p. 686). Their analysis of provincial data showed that for wheat and maize, technical inputs were significant factors for sustaining yields in low rainfall years and rice was more dependent on indicators representing access to labour. These factors were helpful in explaining provincial differences in yield sensitivity to rainfall fluctuations.

The research challenge is underscored by the fact that Tao's and Lobell's results, both based on cli- mate-yield relationships, but at different scales, give contrasting response functions for rice (Tao: positive, Lobell: negative) and wheat (Tao: negative, Lobell: positive). Generating a clearer understanding of the sources of such differences and a better assessment of how much yield variability can be explained by climate factors (and hence incorporated within empirical relationships and crop models) is an important research aim.

\subsection{Process-based crop models}

Crop modelling has been the most widely applied approach in efforts to understand climate impacts. Whilst the principles of climate-yield relationships are well understood (e.g. Easterling et al. 2007), there remains considerable uncertainty in their local-scale detail and interactions with other confounding factors. Crop models generally simulate point estimates of changes in yield which need to be coupled with estimates of cultivated area to obtain changes in production, which may be a more meaningful indicator for policy purposes. This upscaling is particularly difficult for China, due to the variety of cropping systems, levels of production and rapidly evolving patterns of land use and management.

Consistency and comparability issues exist between different crop models; models may incorporate different climate factors to varying levels (e.g. the role of temperature or radiation), and these may be represented through different response functions (Challinor et al. 2009). Thus, different crop models can respond in different ways to the same climate stress. Moreover, impact studies rarely follow standardised protocols for the use of climate scenarios and the assessment and portrayal of uncertainty.

\subsubsection{Growing season and cropping systems}

Future warming, changes in precipitation and soil moisture availability will affect the length of the growing season. For a $1^{\circ} \mathrm{C}$ increase in annual average temperature, the accumulated degree days (dd) $\geq 0^{\circ} \mathrm{C}$ increase by approximately $130 \mathrm{dd}$ in northeast China, 250 dd in north China, 350-450 dd in the Yangtze River basin and south China, 300-350 dd in Yunnan and Guizhou, 250-300 dd in the northwest arid and semiarid regions, and 190 dd in the Qinghai and Tibetan plateaus (Wang 1996). Climate change will also affect the distribution and intensity of cropping systems; for example, for 1 scenario $\left(2 \times \mathrm{CO}_{2}\right)$, the 
potential single cropping area decreased by $23.1 \%$ and the triple cropping area increased from $13.5 \%$ to $36 \%$ (Wang 2002). Under warming conditions and assuming no other limitations (such as water), much of the current double cropping system could be progressively replaced by different combinations of triple cropping systems. The northern limit of double cropping systems could shift to the current centre point of single cropping systems (Wang 2002).

\subsubsection{Crop yield and production}

Most impact studies have concentrated on the yield, production and quality of wheat, rice and maize, the main cereal crops in China (see Appendix 1).

Some important points emerge from these studies, as follows:

(1) Factors such as crop variety, cropping season (complicated by multiple cropping systems), whether crops are irrigated or rain fed, and differences in the spatial patterns of precipitation, radiation and evapotranspiration all contribute to complex spatial patterns of effects on yields and differences between the results of the studies.

(2) China's large size and range of agro-ecological conditions means that sensitivity and exposure can vary considerably. The main spatial patterns are: a tendency for wheat, rice and maize yields to decrease in the southern parts of China, where crops are already grown close to their temperature tolerance and warmer conditions speed up crop maturation; yields tend to increase in central, north and northeastern China benefitting from the longer growing season.

(3) The magnitude and sustainability of the $\mathrm{CO}_{2}$ fertilisation effect on yield is critical to the results (Lin et al. 2005), and whether it is included or not often determines whether overall impacts are positive or negative. Differences among climate model scenarios (Liu et al. 2004) and among impact assessment model and parameter determination (EBNCCA 2007) are also important.

(4) Wheat is more sensitive than rice and maize to the $\mathrm{CO}_{2}$ fertilisation effect. Irrigated maize and wheat are the least sensitive to increased temperature, and rain-fed maize and rice are the most sensitive.

(5) Few studies have considered the effects of changing water availability alongside the direct effects of climate change on crop yields in irrigated areas. These studies tend to show that water availability becomes a limiting factor, primarily through growing demand from non-agricultural sectors (see Section 5.4).
(6) In terms of the 3 main staple crops, rice, wheat and maize, most impact studies suggest that China has the potential to feed itself without needing to rely heavily on the world food markets during the first half of the 21st century (e.g. Xiong et al. 2007, Tao et al. 2008). However, whether the government will choose self-sufficiency or increased food imports may depend on the relative costs of these 2 alternatives (Tao et al. 2008). Demand for other food products such as soy, meat and dairy are increasing rapidly, and much of this demand is likely to be met through imports.

\subsection{Integrating climate change with other drivers}

The interactions between climate change, agriculture and water availability are receiving great attention globally and in China. To assess the policy significance of impact studies, it is necessary to set their results within the context of wider environmental and societal change. Studies of climate change, which do not assume very rapid rates of change or the occurrence of tipping points, generally show modest effects from climate change alone out to the 2050s, relative to drivers such as population growth and increasing per capita consumption. In their review of global food security under climate change, Schmidhuber \& Tubiello (2007) found that most studies only deal with 1 component of food security, viz. availability, without focusing on the other 3: stability, utilisation and access. Developing integrated assessment models and/or tools to assess the comprehensive impacts of direct and indirect climate change and human activities on food security is an ongoing objective in many research programmes. However, each additional component of the system requires greater complexity in modelling and brings additional uncertainties: pursuing their incorporation may highlight interesting non-linear interactions and feedbacks but will require significant resources and time and, not least, careful consideration of how to communicate and use the results from such exercises.

Recent studies have used a variety of models and climate scenarios to analyse the integrated effects of climate change on food production. Several integrated assessments have incorporated water availability (e.g. Rosenberg et al. 2003, 2004) and others have considered different socio-economic development pathways (e.g. Parry et al. 2004, Fischer et al. 2005). Although most of these assessments have been done in developed countries (e.g. Izaurralde et al. 2003, Holman et al. 2005), results for China have 
been referred to in global studies such as Parry et al. (2005). Fischer et al. (2005) inferred that generally higher precipitation projected by GCMs for China will benefit future national food production, but studies by Tao et al. (2003) and Rosenzweig et al. (2004) demonstrated that water scarcity for agriculture will continue with climate change, at least in some of the main food-producing regions (i.e. northeastern and northern China), and even deteriorate due to accompanying changes in non-agricultural demand. Xiong et al. (2009a, 2010) undertook integrated impact assessments of climate change and socioeconomic scenarios on food production in China. They found that although the absolute effects of climate change by 2050 alone were modest, the outcomes were highly dependent on socio-economic development pathways and the effects of $\mathrm{CO}_{2}$ fertilisation on crop yields, and that water availability played a significant role in limiting potential food production. Land degradation and its effects on crop yield is another important driver to consider in such exercises (e.g. Ye \& Van Ranst 2009).

\section{DISCUSSION}

(1) Meteorological hazards are responsible for $71 \%$ of the losses caused by natural hazards annually (Huang et al. 2005). Average grain loss from meteorological hazards reached 50.9 million tons $\mathrm{yr}^{-1}$, and average direct economic loss reached 110.5 billion RMB (US\$ 16.4 billion) during 1996-2003 (D. Wang et al. 2006).

- Research implications: In spite of their importance, the causal links between climate, yield and production are often poorly understood, and detailed evidence for the role of climate as a driver is patchy; data exist across various government departments at a range of spatial and temporal scales. There is a strong case for systematic consolidation and analysis of data on the agricultural, economic and social effects of variability and extreme events. Attribution of agricultural impacts and the mediating effects of autonomous adaptation is made harder due to the rapid pace of change in social-ecological systems in China (e.g. Li et al. 2008, Liu et al. 2008). More detailed meta-analysis of crop yield data (e.g. as in Lobell et al. 2011) and influences on yield and crop model validation are necessary to ensure that crop models simulate observed yield variations. Performance tests could include how well crop models simulate historical fluctuations in production, for example, the effects of the recent drought in Yunnan on crop yields. One additional activity could be as suggested by Sachs et al. (2010), who argued for a global network to monitor the effects of agriculture using a suite of indicators in a systematic way, based on a standard protocol at comparable scales.

(2) Analysis of GCM multi-model results all show a progressive warming in most regions of China, with a consistent shift to moderately wetter conditions in most models, although some seasons and regions have slightly drier conditions in the 2020s. There are marked differences in the detail of sub-national and seasonal to monthly timescale changes.

- Research implications: It is unlikely that this level of uncertainty will narrow significantly over the next 5-10 yr. This implies that crop climate impacts research will need to draw from multiple climate model scenarios and portray uncertainty accurately and in an understandable form to wider audiences. It is difficult to generalise across the results of the many crop modelling and climate impact studies published for China. Crop type, crop variety and whether the crop is irrigated or rain fed all influence crop sensitivity to any given change in temperature and precipitation. China's large size and range of agro-ecological conditions also means that sensitivity and exposure can vary considerably, leading to complex spatial patterns of response.

(3) The magnitude and sustainability of the $\mathrm{CO}_{2}$ fertilisation effect on yield has a critical effect on the outcome of impact studies, but its effects are highly uncertain and may be offset by reductions in grain quality. There are other important uncertainties in the climate-yield response, including the effects of other surface atmospheric pollutants such as ozone, extreme events and interactions with other biophysical factors.

- Research implications: Many research questions are associated with these scientific uncertainties. These encompass more/new field experimentation and observation programmes, meta-analysis of published studies, crop yield data mining, and crop model development and validation. A greater focus on the role of extreme events and pests and diseases also needs to be incorporated throughout the research chain.

(4) Comparisons of studies for China demonstrate that crop yield impacts can vary according to crop model type (Ricardian/econometric, statistical/ empirical and process-based), even with similar climate forcings.

- Research implications: There is a strong case for more rigorous comparison of different crop model types using consistent data sets and simulation 
design. The role of crop model structure, parameterisation and parameter values needs to be explored and characterised in crop impact studies.

(5) There is a common finding that socio-economic development pathways generally outweigh the effects of climate change over the near to mid-term future (e.g. 2050s). Integrated studies of agriculture and water tend to highlight the significance of growing water scarcity (i.e. demand relative to supply), driven largely by increasing societal demand for water, but exacerbated by climate change.

- Research implications: Climate impact studies tend to focus mainly on just 1 component of food security (food availability), without detailed consideration of food stability, access and utilisation. To understand the significance of climate change for food security, it is necessary to set climate impacts within a context of ongoing socio-economic change and adaptation. This is a major challenge and can be addressed through ambitious integrated modelling assessments or through enhanced and continual engagement between crop modellers and other researchers (economists, scenario planners, agricultural policy makers) and end users.

(6) It is likely that climate impact studies will continue to produce a wide range of results for specific crops. Whilst improvements (and possibly convergence) in the simulation of processes in existing models may occur, these may be offset by increasing model complexity and the incorporation of new factors which may lead to divergence in results.

- Research implications: There is a need for a more systematic approach to quantifying sources of uncertainty and presentation of results from climate impact studies. Coordination of benchmark studies of particular crops using different methods could help pinpoint sources and significance of differences in results. In addressing this issue, impacts research may gain greater traction with potential research users. Moreover, research users and decision makers will need to consider management systems and policies which are able to address such high levels of uncertainty. In the context of adaptation, climate impacts research could further integrate within broader framings of food systems research. Given the uncertainties, a critical objective for research should be to answer the question: What are the main properties of an adaptive food security system, and how can they be strengthened or transferred?

Acknowledgements. This work was partly supported by the National Basic Research Program of China (project no. 2010CB951504). D.C. was partly supported through a
Department for International Development (DFID) Senior Research Fellow's position, the Adapting to Climate Change in China project (ACCC, funded by UK DFID, Swiss Development Agency and UK Department of Energy and Climate Change) and a visiting fellowship to the Australian National Climate Change Adaptation Facility. We acknowledge the modelling groups, the Program for Climate Model Diagnosis and Intercomparison and the JSC/CLIVAR Working Group on Coupled Modelling for the GCM multi-model data. Comments from 5 anonymous reviewers improved the manuscript.

\section{LITERATURE CITED}

Bai LP, Tong CF, Lin ED, Xiong W and others (2004) Effects of elevated $\mathrm{CO}_{2}$ on processing quality characteristics of two winter wheat genotypes under CGC experiment system. Proc World Eng Convention. Vol E, agricultural engineering and food security. China Science and Technology Press, Beijing, p 252-256 (in Chinese)

CAAS (Chinese Academy of Agricultural Sciences) (1999) Agrometeorology in China. China Meteorological Press, Beijing (in Chinese)

Challinor AJ, Ewert F, Arnold S, Simelton E, Fraser E (2009) Crops and climate change: progress, trends, and challenges in simulating impacts and informing adaptation. J Exp Bot 60:2775-2789

Chen Y, Chen XY, Ren GY (2010) Variation of extreme precipitation over the Chinese large river basins in the last 53 years. Adv Clim Change Res 6:265-269 (in Chinese with English abstract)

Christensen JH, Hewitson B, Busuioc A, Chen A and others (2007) Regional climate projections. In: Solomon S, Qin D, Manning M, Chen Z and others (eds) Climate change 2007: the physical science basis. Contribution of Working Group I to the Fourth Assessment Report of the Intergovernmental Panel on Climate Change. Cambridge University Press, Cambridge, p 847-940

Cline W (1996) The impact of global warming on agriculture. Am Econ Rev 86:1309-1312

CMA (China Meteorological Administration) (2005-2010) Yearbook of meteorological disasters in China. China Meteorological Press, Beijing (in Chinese)

CPGC (The Central People's Government of the People's Republic of China) (2008) Extreme low temperature and heavy snow has caused a direct economic loss of 151.65 billion Yuan RMB. Available at www.gov.cn/ztzl/200804/22/content_951622.htm (in Chinese)

Cui QJ (2005) Evaluation of the effect of future climate change on maize production in China. MSc thesis. China Agriculture University, Beijing (in Chinese with English abstract)

Ding YH, Ren GY, Zhao ZC, Xu Y, Luo Y, Li QP, Zhang J (2007) Detection, causes and projection of climate change over China: an overview of recent progress. Adv Atmos Sci 24:954-971 (in Chinese with English abstract)

> Dong J, Liu J, Tao F, Xu X, Wang J (2009) Spatio-temporal changes in annual accumulated temperature in China and the effects on cropping systems, 1980s to 2000. Clim Res 40:37-48

DRS (Department of Rural Survey, National Bureau of Statistics) (2005) China yearbook of rural household survey. China Statistics Press, Beijing (in Chinese)

Easterling WE, Aggarwal PK, Batima P, Brander KM and 
others (2007) Food, fiber and forest products. In: Parry ML, Canziani OF, Palutikof JP, van der Linden PJ, Hanson CE (eds) Climate change 2007: impacts, adaptation and vulnerability. Contribution of Working Group II to the Fourth Assessment Report of the Intergovernmental Panel on Climate Change. Cambridge University Press, Cambridge, p 273-313

EBCAY (Editorial Board of China Agricultural Yearbook) (2005-2007) China agriculture yearbook. China Agricultural Press, Beijing (in Chinese)

EBNCCA (Editorial Board of National Climate Change Assessment) (2007) National climate change assessment report. Science Press, Beijing (in Chinese with English abstract)

EBNCCA (2011) Second national climate change assessment report. Science Press, Beijing (in Chinese)

Fang X, Wang G, Zhu X (2005) Change of cool summer hazard under an adaptation behavior to the climate warming in Heilongjiang Province, Northeast China. Geogr Res 24:664-672

Fischer G, Shah M, Tubiello FN, van Velhuizen H (2005) Socio-economic and climate change impacts on agriculture: an integrated assessment, 1990-2080. Philos Trans R S Lond B Biol Sci 360:2067-2083

> Fischer G, Tubiello FN, Velthuizen H, Wiberg DA (2007) Climate change impacts on irrigation water requirements: effects of mitigation, 1990-2080. Technol Forecast Soc Change 74:1083-1107

Fraser E, Termansen M, Sun N, Guan D and others (2008) Quantifying socio economic characteristics of drought sensitive regions: evidence from Chinese provincial agricultural data. C R Geosci 340:679-688

Gao SH, Wang CY (1994) The impact of elevated $\mathrm{CO}_{2}$ concentration on composition of winter wheat and soybean. Environ Sci 15:24-30 (in Chinese with English abstract)

Ge DK, Jin ZQ, Shi CL, Gao LZ (2002) Gradual impacts of climate change on rice production and adaptation strategies in southern China. Jiangsu J Agric Sci 18:1-8 (in Chinese with English abstract)

Gong DJ (1995) Temperature increase in last 40 years and droughts in Inner Mongolia. J Meteorol Inner Mongolia 1:16-21 (in Chinese)

Hewitt K (2010) Understanding glacier changes. Available at www.chinadialogue.net/article/show/single/en/3481

> Holman IP, Nicholls RJ, Berry PM, Harrison PA, Audsley E, Shackley S, Rounsevell MDA (2005) A regional, multisectoral and integrated assessment of the impacts of climate and socio-economic change in the UK: Part II. Results. Clim Change 71:43-73

Huang RH, Zhang QY, Ruan SG (2005) Meteorological disaster forecasting and early warning in China and disaster prevention and reduction countermeasures. China Meteorological Press, Beijing, p 3-22 (in Chinese)

Hu Z, Yang S, Wu R (2003) Long-term climate variations in China and global warming signals. J Geophys Res 108 (D19), 4614, doi:10.1029/2003JD003651

Hulme M (1992) Climate change due to the greenhouse effect and its implications for China. WWF-World Wide Fund for Nature, University of East Anglia, Norwich

IPCC (Intergovernmental Panel on Climate Change) (2001) Climate change 2001: the scientific basis. Contribution of Working Group I to the Third Assessment Report of the Intergovernmental Panel on Climate Change. Cambridge University Press, Cambridge

IPCC (2007a) Climate change 2007: the physical science basis. Contribution of Working Group I to the Fourth Assessment Report of the Intergovernmental Panel on Climate Change. Cambridge University Press, Cambridge IPCC (2007b) Climate change 2007: impacts, adaptation and vulnerability. Contribution of Working Group II to the Fourth Assessment Report of the Intergovernmental Panel on Climate Change. Cambridge University Press, Cambridge

Izaurralde RC, Rosenberg NJ, Brown RA, Thomson AM (2003) Integrated assessment of Hadley Center (Had CM2) climate-change impacts on agricultural productivity and irrigation water supply in the conterminous United States: Part II. Regional agricultural production in 2030 and 2095. Agric For Meteorol 117:97-122

Jiang M, Jin ZQ, Gao LZ (1998) Gradual impacts of climate change on winter wheat production in China. Jiangsu J Agric Sci 14:90-95 (in Chinese with English abstract)

Ju H, Xiong W, Xu YL, Lin ED (2005) Impacts of climate change on wheat production in China. Acta Agron Sin 31:1340-1343 (in Chinese with English abstract)

Kingdon J (2003) Agendas, alternatives and public policies, 2nd edn. Little Brown, New York, NY

Li H (2000a) Studies on the impacts of meteorological disasters, pests and diseases on agricultural development. In: Liu J (ed) Development strategy for Chinese agriculture during the early stage of 21st century. China Agricultural Press, Beijing, p 401-426 (in Chinese with English abstract)

Li X, Zhou X, Li W, Chen L (1995) The cooling of Sichuan Province in recent 40 years and its probable mechanism. Acta Meteorol Sin 9:57-68 (in Chinese with English abstract)

Li Y (2000b) Studies on land resources protection and rational utilization. In: Liu J (ed) Development strategy for Chinese agriculture during the early stage of $21 \mathrm{st}$ century. China Agricultural Press, Beijing, p 67-78 (in Chinese)

Li Y, Wu Y, Conway D, Preston F and others (2008) Climate and livelihoods in rural Ningxia: final report. AEA Group, London

Li YH (2006) Water saving irrigation in China. Irrig Drainage 55:327-336 (in Chinese)

Lin ED, Xiong W, Ju H, Xu Y, Li Y, Bai L, Xie L (2005) Climate change impacts on crop yield and quality with $\mathrm{CO}_{2}$ fertilization in China. Phil Trans R Soc Lond B Biol Sci 2005:1-7

Liu C, Golding D, Gong G (2008) Farmers' coping response to the low flows in the lower Yellow River: a case study of the temporal dimensions of variability. Glob Environ Change 18:543-553

Liu H, Li XB, Fischer G, Sun LX (2004) Study on the impacts of climate change on China's agriculture. Clim Change 65:125-148

Liu L, Sha Y, Bai YM (2003) Regional distribution of major agrometeorological disasters and associated mitigation strategies in China. J Nat Disasters 12:92-97 (in Chinese with English abstract)

Liu YQ, Song JJ, Zhang QJ (2005) Research on impacts of drought on Chinese socioeconomy. Hydrological Publication House, Beijing (in Chinese)

> Liu ZJ, Yang XG, Wang WF, Li KN, Zhang XY (2009) Characteristics of agricultural climate resources in three provinces of northeast China under global climate change. Chin J Appl Ecol 20:2199-2206 (in Chinese with English abstract) 
Lobell DB, Burke MB, Tebaldi C, Mastrandrea MD, Falcon WP, Naylor RL (2008) Prioritising climate change adaptation needs for food security in 2030. Science 319:607-610

Lobell DB, Bänziger M, Magorokosho C, Vivek B (2011) Nonlinear heat effects on African maize as evidenced by historical yield trials. Nat Clim Change 1:42-45 doi: 10.1038/nclimate1043

Lu PL, Yu Q, Wang E, Liu JD, Xu SH (2008) Effects of climatic variation and warming on rice development across South China. Clim Res 36:79-88

MCA (Ministry of Civil Affairs of the People's Republic of China) (2010a) Reports of drought status and control measures by MCA. Available at www.mca.gov.cn/article/ zwgk/mzyw/201003/20100300064033.shtml (in Chinese)

MCA (2010b) MCA supports flood-stricken areas to guarantee basic needs of local people. Available at www. mca.gov.cn/article/zwgk/mzyw/201008/20100800096499. shtml (in Chinese)

Meehl GA, Stocker TF, Collins WD, Friedlingstein P and others (2007) Global climate projections. In: Solomon S, Qin D, Manning M, Chen Z and others (eds) Climate change 2007: the physical science basis. Contribution of Working Group I to the Fourth Assessment Report of the Intergovernmental Panel on Climate Change. Cambridge University Press, Cambridge

Mendelsohn R, Nordhaus W, Shaw D (1994) Measuring the impact of global warming on agriculture. Am Econ Rev 84:753-771

MoWR (Ministry for Water Resources) (2001-2005) Statistic Bulletins on China Water Activities. China Water Resources and Electric Power Press, Beijing

NBSC (National Bureau of Statistics of China) (1996, 1997, 2004, 2005, 2006, 2009) China statistical yearbook. China Statistics Press, Beijing (in Chinese)

NCC (National Climate Center) (2010) The impact of climate in China during 2009. China Meteorological Press, Beijing (in Chinese)

NDRC (National Development and Reform Commission) (2004) The People's Republic of China initial national communication (INC) on climate change. China Planning Press, Beijing

NDRC (2007) China's national climate change programme. Available at http://wenku.baidu.com/view/87afa8b665 ce0508763213d2.html (in Chinese)

Parry M, Rosenzweig C, Livermore M (2005) Climate change, global food supply and risk of hunger. Phil Trans R Soc Lond B Biol Sci 360:2125-2138

Parry ML, Rosenzweig C, Iglesias A, Livermore M, Fischer G (2004) Effects of climate change on global food production under SRES emissions and socio-economic scenarios. Glob Environ Change 14:53-67

Penning-Rowsell E, Johnson C, Tunstall S (2006) 'Signals' from pre-crisis discourse: lessons from UK flooding for global environmental policy change? Glob Environ Change 16:323-339

Qiu J (2010) China drought highlights future climate threats. Nature 465:142-143

Ren GY, Guo J, Xu MZ, Chu ZY and others (2005) Climate changes of China's mainland over the past half century. Acta Meteorol Sin 63:942-956 (in Chinese)

> Rosenberg NJ, Brown RA, Izaurralde RC, Thomson AM (2003) Integrated assessment of Hadley Centre (HadCM2) climate change projections on agricultural productivity and irrigation water supply in the conterminous United States: I. Climate change scenarios and impacts on irrigation water supply simulated with the HUMUS model. Agric For Meteorol 117:73-96

Rosenzweig C, Strzepek KM, Major DC, Iglesias A, Yates DN, McCluskey A, Hillel D (2004) Water resources for agriculture in a changing climate: international case studies. Glob Environ Change 14:345-360

> Rothausen SGSA, Conway D (2011) Greenhouse-gas emissions from energy use in the water sector. Nat Clim Change 1:210-219

Royal Society (2005) Food crops in a changing climate. Royal Society, London

Ruan JS (2000) Meteorological disasters. China Meteorological Press, Beijing (in Chinese)

Sachs J, Remans R, Smukler S, Winowiecki L and others (2010) Monitoring the world's agriculture. Nature 466: $558-560$

> Schmidhuber J, Tubiello FN (2007) Global food security under climate change. Proc Natl Acad Sci USA 104: 19703-19708

Shi YF (2003) Assessment of climate pattern change from warm-dry to warm-wet in northwest of China. Meteorological Press, Beijing (in Chinese)

Smith PE, Olesen JE (2010) Synergies between the mitigation of, and adaptation to, climate change in agriculture. J Agric Sci 148:543-552

SOA (State Oceanic Administration) (2007) China's sea level bulletin 2007. Available at http://wenku.baidu.com/view/ e2ca4e40a8956bec0975e333.html (in Chinese)

Song Y, Linderholm H, Chen D, Walther A (2010) Trends of the thermal growing season in China, 1951-2007. Int J Climatol 30:33-43

Sun LF (1997) Strategies for winter wheat breeding in Heilongjiang. Heilongjiang Agric Sci 4:26-27 (in Chinese with English abstract)

Tao FL, Yokozawa M, Hayashi Y, Lin ED (2003) Future climate change, the agricultural water cycle, and agricultural production in China. Agric Ecosyst Environ 95: 203-215

Tao FL, Yokozawa M, Liu JY, Zhang Z (2008) Climate-crop yield relationships at provincial scales in China and the impacts of recent climate trends. Clim Res 38:83-94

Wang CY, Guo JP, Cui DC, Wang XL, Liang H, Xu SH (2000) The experimental research about the effects of $\mathrm{CO}_{2}$ enrichment on wheat and corn quality. Acta Agron Sin 26:931-935 (in Chinese with English abstract)

Wang DL, Zhong XL, Li MS, Yang X (2006) Impacts of major agro-meteorological disasters in China. J Catastrophol 21:18-22 (in Chinese)

Wang FT (2002) Advances in climate warming impact research in China in recent ten years. J Appl Meteorol Sci 13:756-766

Wang FT, Zhao ZC, Wang SL, Liu WQ (2003) Impacts of climate change on agro-ecosystems. China Meteorological Press, Beijing (in Chinese with English abstract)

Wang JA, Sun H, Xu W, Zhou J (2006) Spatio-temporal change of drought disaster in China in recent fifty years. J Catastrophol 11:1-6 (in Chinese with English abstract)

Wang J, Mendelsohn R, Dinar A, Huang J, Rozelle S, Zhang L (2009) The impact of climate change on China's agriculture. Agric Econ 40:323-337 (in Chinese with English abstract)

Wang SC (2006) Changing water use concept and innovating development pattern. South-North Water Diversion and Water Conservancy Science and Technolgy 2: 1672-1683 
Wang XL (1996) $\mathrm{CO}_{2}$, climate change and agriculture. China Meteorological Press, Beijing (in Chinese)

Wilby RL, Troni J, Biot Y, Tedd L, Hewitson BC, Smith DM, Sutton RT (2009) A review of climate risk information for adaptation and development planning. Int J Climatol 29: 1193-1215

Wu K, Lu B, Yuan Z (2006) The recent developments and the contribution of farmland irrigation to national grain safeness in China. J Irrig Drainage 25:7-10 (in Chinese)

Xiong W, Xu YL, Lin ED, Lu ZG (2005a) Regional simulation of maize production under IPCC SRES A2 and B2 scenarios. J Chin Agrometeorol 26:11-15 (in Chinese with English abstract)

Xiong W, Xu YL, Lin ED, Lu ZG (2005b) Regional simulation of rice yield change under two emission scenarios of greenhouse gases. Chin J Appl Ecol 16:65-68 (in Chinese with English abstract)

Xiong W, Ju H, Xu YL, Lin ED (2006) The threshold of temperature increase due to climate change for Chinese agriculture and its uncertainties. Adv Earth Sci 21:70-76 (in Chinese with English abstract)

Xiong W, Lin E, Ju H, Xu Y (2007) Climate change and critical thresholds in China's food security. Clim Change 81: 205-221

Xiong W, Conway D, Xu YL, Jinhe J, Ju H, Lin ED (2008a) The impacts of climate change on Chinese agriculturephase II national level study: the impacts of climate change on cereal production in China. Final Report. AEA Group, London

Xiong W, Yang J, Lin ED, Xu YL (2008b) The projection of maize yield in China under climate change scenarios. Adv Earth Sci 23:1092-1101 (in Chinese with English abstract)

Xiong W, Conway D, Lin E, Xu Y and others (2009a) Future cereal production in China: the interaction of climate change, water availability and socio-economic scenarios. Glob Environ Change 19:34-44

Xiong W, Conway D, Lin ED, Holman I (2009b) Potential impacts of climate change and impact variability on China's rice yield and production. Clim Res 40:23-35

Xiong W, Holman I, Lin E, Conway D, Jiang J, Xu Y, Li Y (2010) Climate change, water availability and future cereal production in China. Agric Ecosyst Environ 135:58-69

Xu YL, Huang XY, Zhang Y, Lin W, Lin E (2005) Statistical analyses of climate change scenarios over China in the 21st century. Adv Clim Change Res 1:80-83

Yang HL, Xu YL, Zhang L, Pan J, Li X (2010) Projected change in heat waves over China using the PRECIS climate model. Clim Res 42:79-88

Yang HS, Hou LB, Feng YX, Wang Y, Pang XB (2000) Feasibility analysis of growing winter wheat over Xiliaohe Plains in Inner Mongolia. Agric Prod Dev 4:20-24 (in Chinese)

Yang X, Lin ED, Ma SM, Ju H and others (2007) Adaptation of agriculture to warming in Northeast China. Clim Change 84:45-58

Yang XG, Liu ZJ, Chen F (2010) The possible effects of global warming on cropping systems in China 1. The possible effects of climate warming on northern limits of cropping systems and crop yields in China. Sci Agric Sin 43:329-336 (in Chinese with English abstract)

Yao FM, Xu YL, Lin ED, Yokozawa M, Zhang JH (2007) Assessing the impacts of climate change on rice yields in the main rice areas of China. Clim Change 80:395-409

Ye L, Van Ranst E (2009) Production scenarios and the effect of soil degradation on long-term food security in China. Glob Environ Change 19:464-481

Zhai PM, Zhang XB, Wan H, Pan XH (2005) Trends in total precipitation and frequency of daily precipitation extremes over China. J Clim 18:1096-1108 (in Chinese with English abstract)

Zhang HX (2000) The problems concerning the response of China's cropping systems to global climatic changes. The effects of climatic changes on cropping systems in China. Agric Meteorol 21:9-13 (in Chinese with English abstract)

Zhang JR (2002) Reasonable water resources management. In: Liu J (ed) Strategies on resources utilization in China. Chinese Agricultural Press, Beijing, p 64-65 (in Chinese)

Zhang JY, Zhang SL, Li Y (2004) Climate change in hydrology. Proc Stud Adv Sci Technol Hydrol China, Jiangsu. Hehai University Press, Nanjing

Zhang X (1999) Drought and flooding disasters and poverty in rural area of China. Chin Rural Econ 11:12-18 (in Chinese)

Zhang Y, Xu YL, Dong WJ, Cao LJ (2006) Change of extreme precipitation events in China in future: an analysis based on projection of climate change. J Nat Disast 15: 228-234 (in Chinese)

Zhang YC (1991) Impacts of meteorological disasters on agriculture in China. China Meteorological Press, Beijing (in Chinese)

Zhao J, Yang X, Liu Z (2009) Influence of climate warming on serious low temperature and cold damage and cultivation pattern of spring maize in Northeast China. Acta Ecol Sin 29:6544-6551 (in Chinese with English abstract)

Zhao JK, Leng CM, Jiao SX (2004) Analysis of China's floods in recent years and associated response strategies. J Mod Ecoagric 1:12-15 (in Chinese)

Zheng YR, Zhou GS, Zhang XS, Wang JL, Tai HJ (1997) An agricultural net primary productivity model. Acta Bot Sin 39:831-836 (in Chinese with English abstract)

Zou XK, Ren GY, Zhang Q (2010) Drought variations in China based on a compound index of meteorological drought. Clim Environ Res 15:371-378 (in Chinese)

Zhu ZW, Jin ZQ (2008) Impacts of changes in both climate and its variability on food production in northeast China. Acta Agron Sin 34:1588-1597 (in Chinese with English abstract) 
Appendix 1. Climate impact studies of agriculture in China. Temperature change represents either global/China/case study average increase from climate models or sensitivity study (e.g. $\Delta \mathrm{T}$ )

\begin{tabular}{|c|c|c|c|c|}
\hline Variable & Model & $\begin{array}{l}\text { Climate change } \\
\text { scenario }\end{array}$ & Results & Source \\
\hline \multicolumn{5}{|c|}{ Temperature change $1-2^{\circ} \mathrm{C}$} \\
\hline Wheat & CERES-Wheat & $\mathrm{RCM}, \mathrm{A} 2$ and $\mathrm{B} 2$ & $\begin{array}{l}\text { With } \mathrm{CO}_{2} \text { effect: Average yield increases by } 5 \sim 15 \% \\
\text { Without } \mathrm{CO}_{2} \text { effect: Average yield decreases by } 0.5-18.5 \% \text {. }\end{array}$ & Lin et al. (2005) \\
\hline Wheat & CERES-Wheat & $\begin{array}{l}\text { GISS GCM } \\
\text { Transient Run }\end{array}$ & $\begin{array}{l}\text { For rain-fed wheat, yield decreases by } 30 \% \text { in the middle and } \\
\text { lower reaches of the Yangtze River, } 5 \% \text { in north China. Yield } \\
\text { increases by } 14 \% \text { in the Huang-Huai-Hai Plain, and } 5 \% \text { in } \\
\text { southwest China. For irrigated wheat, yield decreases by } 3 \% \\
\text { and } 1 \% \text { in north China and the Huang-Huai-Hai Plain, respec- } \\
\text { tively, and increases by } 6 \% \text { in southwest China. }\end{array}$ & Jiang et al. (1998) \\
\hline Rice & CERES-Rice & $\mathrm{RCM}, \mathrm{A} 2$ and $\mathrm{B} 2$ & $\begin{array}{l}\text { Average yield increases by } 2-4 \% \text { under A2, no changes under B2 } \\
\text { with } \mathrm{CO}_{2} \text { effect. Average yield decreases by } 1-13 \% \text { without } \mathrm{CO}_{2} \text {. }\end{array}$ & Lin et al. (2005) \\
\hline Rice & CERES-Rice & $\begin{array}{l}\text { GISS GCM } \\
\text { Transient Run }\end{array}$ & $\begin{array}{l}\text { For single rice in central and southwest China, yield increases } \\
\text { by } 5-8 \% \text {. For early and late rice in central and south China, } \\
\text { yield decreases by } 1-3 \% \text {. }\end{array}$ & Ge et al. (2002) \\
\hline Maize & CERES-Maize & $\mathrm{RCM}, \mathrm{A} 2$ and $\mathrm{B} 2$ & $\begin{array}{l}\text { With } \mathrm{CO}_{2} \text { effect: Average rain-fed maize yield increases by } \\
1-10 \% \text { and irrigated maize yield decreases by } 0.1-0.6 \% \text {. } \\
\text { Without } \mathrm{CO}_{2} \text { effect: Average rain-fed maize yield decreases by } \\
10-11 \% \text { and irrigated maize yield ranges from } 0.2 \% \text { to }-5 \% \text {. }\end{array}$ & Lin et al. (2005) \\
\hline \multirow[t]{2}{*}{$\begin{array}{l}\text { Farm net } \\
\text { revenue }\end{array}$} & Ricardian Model & HadCM2-gs & $\begin{array}{l}\text { Negative impacts on agricultural revenue in northeast China, } \\
\text { but with overall increase of agricultural revenue by } 28 \% \text {. }\end{array}$ & Liu et al. (2004) \\
\hline & $\begin{array}{l}\text { Crop-specific } \\
\text { soil-water } \\
\text { balance model }\end{array}$ & HadCM2 & $\begin{array}{l}\text { Agricultural water demand in south China is projected to } \\
\text { decrease generally, and the cropland soil-moisture deficit } \\
\text { decreases. In north China, agricultural water demand increases, } \\
\text { and the soil-moisture deficit increases. }\end{array}$ & Tao et al. (2003) \\
\hline \multicolumn{5}{|c|}{ Temperature change $2-3^{\circ} \mathrm{C}$} \\
\hline Wheat & CERES-Wheat & $\mathrm{RCM}, \mathrm{A} 2$ and $\mathrm{B} 2$ & $\begin{array}{l}\text { With } \mathrm{CO}_{2} \text { effect: Average yield increases by } 7-20 \% \text {. } \\
\text { Without } \mathrm{CO}_{2} \text { effect: Average yield decreases by } 2-20 \% \text {. }\end{array}$ & Lin et al. (2005) \\
\hline Wheat & CERES-Wheat & $\begin{array}{l}\text { GISS GCM } \\
\text { Transient Run }\end{array}$ & $\begin{array}{l}\text { For rain-fed wheat, yield decreases by } 28 \% \text { in the middle and } \\
\text { lower reaches of Yangtze River, and } 3 \% \text { in northern China. } \\
\text { Yield increases by } 20 \% \text { and } 12 \% \text { in the Huang-Huai-Hai plain } \\
\text { and southwest China, respectively. For irrigated wheat, yield } \\
\text { decreases by } 6 \% \text { in northern China while in the Huang-Huai- } \\
\text { Hai plain and southwest China, it increases by } 1 \% \text { and } 6 \% \text {, } \\
\text { respectively. }\end{array}$ & Jiang et al. (1998) \\
\hline Rice & CERES-Rice & $\begin{array}{l}\text { GISS GCM } \\
\text { Transient Run }\end{array}$ & $\begin{array}{l}\text { For single rice culture in central China and southwest China, } \\
\text { yield increases by } 4-6 \% \text {. For early and late rice in central and } \\
\text { southern China, yield decreases by } 2-7 \% \text {. }\end{array}$ & Ge et al. (2002) \\
\hline Maize & CERES-Maize & $\mathrm{RCM}, \mathrm{A} 2$ and $\mathrm{B} 2$ & $\begin{array}{l}\text { With } \mathrm{CO}_{2} \text { effect: Average rain-fed maize yield increases by } \\
9-18 \% \text { and irrigated maize yield decreases by } 1-2 \% \text {. } \\
\text { Without } \mathrm{CO}_{2} \text { effect: Average yield decreases by } 0.4-23 \% \text {. }\end{array}$ & Lin et al. (2005) \\
\hline Maize & CERES-Maize & $\mathrm{RCM}, \mathrm{A} 2$ and $\mathrm{B} 2$ & $\begin{array}{l}\text { Irrigated maize production decreases by } 8 \% \text { and rain-fed maize } \\
\text { production decreases by } 0.7 \% \text {. }\end{array}$ & Xiong et al. (2005a) \\
\hline $\begin{array}{l}\text { Crop } \\
\text { produc- } \\
\text { tivity }\end{array}$ & $\begin{array}{l}\text { Agricultural } \\
\text { NPP model }\end{array}$ & $\begin{array}{l}+2^{\circ} \mathrm{C} \text {, precipitation } \\
\text { increase } 20 \% \text {, or } \\
\text { decrease } 20 \% \text {, or no } \\
\text { change }\end{array}$ & $\begin{array}{l}\text { Productivity increases by } 0.4-13 \% \text { with } 2^{\circ} \mathrm{C} \text { warming and } \\
\text { precipitation unchanged or increased by } 20 \% \text {; increase by } \\
1.5-14.6 \% \text { in humid areas, decrease by } 0.4-2.9 \% \text { in arid and } \\
\text { semiarid areas. Water was a key factor in agricultural impacts. }\end{array}$ & Zheng et al. (1997) \\
\hline $\begin{array}{l}\text { Agri- } \\
\text { culture }\end{array}$ & $\begin{array}{l}\text { Ricardian } \\
\text { Model }\end{array}$ & HadCM2-gx & $\begin{array}{l}\text { Negative impacts on agricultural revenue in northeast southwest } \\
\text { China. The overall increase of agricultural revenue is } 24 \% \text {. }\end{array}$ & Liu et al. (2004) \\
\hline $\begin{array}{l}\text { economy } \\
\text { Food } \\
\text { security }\end{array}$ & & & $\begin{array}{l}\text { Without } \mathrm{CO}_{2} \text { effect: temperature threshold for threatening food } \\
\text { security in China would be } 2.0 \sim 2.5^{\circ} \mathrm{C} \text {. Considering adaptation } \\
\text { and } \mathrm{CO}_{2} \text { effects temperature threshold is over } 4^{\circ} \mathrm{C} \text {. }\end{array}$ & Xiong et al. (2006) \\
\hline
\end{tabular}


Appendix 1 (continued)

\begin{tabular}{|c|c|c|c|c|}
\hline Variable & Model & $\begin{array}{l}\text { Climate change } \\
\text { scenario }\end{array}$ & Results & Source \\
\hline \multicolumn{5}{|c|}{ Temperature change $3-5^{\circ} \mathrm{C}$} \\
\hline Wheat & CERES-Wheat & $\mathrm{RCM}, \mathrm{A} 2$ and B2 & $\begin{array}{l}\text { Without } \mathrm{CO}_{2} \text { : rain-fed wheat yield increases with rates of } \\
0-30 \% \text { in the North China Plain and the middle and lower } \\
\text { reaches of the Yangtze River; spring wheat yield (in the } \\
\text { northeast and northwest of China) and winter wheat yield in } \\
\text { the southwest of China decrease significantly, } 30-60 \% \text { by } \\
\text { the } 2070 \text { s compared with base year (1961-1990). }\end{array}$ & Ju et al. (2005) \\
\hline Wheat & CERES-Wheat & $\mathrm{RCM}, \mathrm{A} 2$ and $\mathrm{B} 2$ & $\begin{array}{l}\text { Without } \mathrm{CO}_{2} \text { effect: National average yield of rain-fed wheat } \\
\text { in China decreases } 30-35 \% \text { for spring wheat and } 10-15 \% \\
\text { for winter wheat, overall average yield of irrigated wheat } \\
\text { decreases by } 20 \% \text { and } 19 \% \text {, under A2 and B2, respectively. }\end{array}$ & Ju et al. (2005) \\
\hline Wheat & CERES-Wheat & $\mathrm{RCM}, \mathrm{A} 2$ and $\mathrm{B} 2$ & $\begin{array}{l}\text { With } \mathrm{CO}_{2} \text { : For irrigated wheat, the yield increases } 4.0 \% \text { and } \\
3.5 \% \text { under A2 and } \mathrm{B} 2 \text {, respectively. }\end{array}$ & Ju et al. (2005) \\
\hline Wheat & CERES-Wheat & $\mathrm{RCM}, \mathrm{A} 2$ and $\mathrm{B} 2$ & $\begin{array}{l}\text { Average wheat yield increases by } 13-40 \% \text { with } \mathrm{CO}_{2} \text {. Average } \\
\text { wheat yield decreases by } 8-22 \% \text { without } \mathrm{CO}_{2} \text {. }\end{array}$ & Lin et al. (2005) \\
\hline Wheat & CERES-Wheat & $\begin{array}{l}\text { GISS GCM } \\
\text { Transient Run }\end{array}$ & $\begin{array}{l}\text { Both rain-fed and irrigated wheat yield decrease in the middle } \\
\text { and lower reaches of the Yangtze River, north China, and } \\
\text { southwest China and increase in the Huang-Huai-Hai plain. }\end{array}$ & Jiang et al. (1998) \\
\hline Rice & CERES-Rice & $\begin{array}{l}\text { GISS GCM } \\
\text { Transient Run }\end{array}$ & $\begin{array}{l}\text { For single rice in central and southwest China, the yield } \\
\text { increases by } 2-5 \% \text {. For early and late rice in central and south } \\
\text { China, the yield decreases by } 10-15 \% \text {. }\end{array}$ & Ge et al. (2002) \\
\hline Rice & CERES-Rice & RCM, A2 and B2 & $\begin{array}{l}\text { Without } \mathrm{CO}_{2} \text { effect: Average rain-fed maize yield increases by } \\
10-20 \% \text { and irrigated maize yield decreases by } 2-3 \% \text { with } \\
\mathrm{CO}_{2} \text {. Average yield decreases by } 4-36 \% \text {. }\end{array}$ & Lin et al. (2005) \\
\hline Rice & CERES-Rice & $\mathrm{RCM}, \mathrm{A} 2$ and $\mathrm{B} 2$ & $\begin{array}{l}\text { Irrigated rice production increases by } 3.4 \% \text { and decreases by } \\
9 \% \text { under A2 and B2, respectively. Rain-fed rice production } \\
\text { increases by } 18 \% \text { and decreases by } 3 \% \text { under A2 and B2, } \\
\text { respectively. }\end{array}$ & Xiong et al. (2005b) \\
\hline Maize & CERES-Maize & $\mathrm{RCM}, \mathrm{A} 2$ and B2 & $\begin{array}{l}\text { Spring maize yield in northeast China decreases by less than } \\
15 \% \text { under both A2 and B2 scenarios. In the Huang-Huai-Hai } \\
\text { plain, summer maize yield increases by less than } 10 \% \text { under } \\
\text { both A2 and B2 scenarios. }\end{array}$ & Cui (2005) \\
\hline Maize & CERES-Maize & $\mathrm{CM}, \mathrm{A} 2$ and $\mathrm{B} 2$ & $\begin{array}{l}\text { Irrigated maize production decreases by } 10 \% \text {; rain-fed maize } \\
\text { production decreases by } 0.1 \% \text {. }\end{array}$ & Xiong et al. (2005a) \\
\hline $\begin{array}{l}\text { Agri- } \\
\text { culture } \\
\text { economy }\end{array}$ & $\begin{array}{l}\text { Ricardian } \\
\text { Model }\end{array}$ & $\begin{array}{l}\text { RCGCM1-gg } \\
\text { CGCM1-gs } \\
\text { ECHAM4-gg }\end{array}$ & $\begin{array}{l}\text { ECHAMM4-greenhouse gas scenario has negative impacts on } \\
\text { agricultural revenue in the northeast and northwest of China. } \\
\text { The overall impact on agricultural revenue is positive (12\%). } \\
\text { The overall agricultural revenue decreases by } 69 \% \text { and } 68 \% \\
\text { under the CG-gs and CG-gg scenarios, respectively. }\end{array}$ & Liu et al. (2004) \\
\hline Rice & CERES-Rice & RCM A2 and B2 & $\begin{array}{l}\text { With or without } \mathrm{CO}_{2} \text { effects, projected climate change sce- } \\
\text { narios produced higher year-to-year variability in yields, as } \\
\text { expressed by the coefficient of variation, relative to that of } \\
\text { the baseline period. }\end{array}$ & Xiong et al. (2009b) \\
\hline Rice & CERES-Rice & RCM B2 & $\begin{array}{l}\text { Without } \mathrm{CO}_{2} \text { : frequency of low yield and variance in rice yield } \\
\text { increase. }\end{array}$ & Yao et al. (2007) \\
\hline Maize & CERES-Maize & RCM A2 and B2 & $\begin{array}{l}\text { Climate variability was projected to increase, leading to an } \\
\text { increased possibility of low yields and increased variability of } \\
\text { annual production. }\end{array}$ & Xiong et al. (2008b) \\
\hline $\begin{array}{l}\text { Soybean, } \\
\text { maize, wh } \\
\text { rice }\end{array}$ & $\begin{array}{l}\text { CERES } \\
\text { heat, }\end{array}$ & $\Delta \mathrm{T}, \Delta \mathrm{P}$ & $\begin{array}{l}\text { Variability of yield in rain-fed crops is correlated to the varia- } \\
\text { bility of rainfall; climate change increases yield variability in } \\
\text { rain-fed crops, such as soybean, maize and spring wheat. }\end{array}$ & Zhu \& Jin (2008) \\
\hline
\end{tabular}

